\title{
Organic carbon and nitrogen export from a tropical dam-impacted floodplain system
}

\author{
R. Zurbrügg ${ }^{1,2}$, S. Suter ${ }^{1}$, M. F. Lehmann ${ }^{3}$, B. Wehrli ${ }^{1,2}$, and D. B. Senn ${ }^{1,2}$ \\ ${ }^{1}$ Institute of Biogeochemistry and Pollutant Dynamics, ETH Zurich, Universitätstrasse 16, 8092 Zurich, Switzerland \\ ${ }^{2}$ Eawag, Swiss Federal Institute of Aquatic Science and Technology, Surface Waters - Research and Management, \\ Seestrasse 79, 6047 Kastanienbaum, Switzerland \\ ${ }^{3}$ Institute of Environmental Geosciences, University of Basel, Bernoullistrasse 30, 4056 Basel, Switzerland
}

Correspondence to: R. Zurbrügg (roland.zurbruegg@env.ethz.ch)

Received: 31 May 2012 - Published in Biogeosciences Discuss.: 28 June 2012

Revised: 12 November 2012 - Accepted: 29 November 2012 - Published: 4 January 2013

\begin{abstract}
Tropical floodplains play an important role in organic matter transport, storage, and transformation between headwaters and oceans. However, the fluxes and quality of organic carbon (OC) and organic nitrogen (ON) in tropical river-floodplain systems are not well constrained. We explored the quantity and characteristics of dissolved and particulate organic matter (DOM and POM, respectively) in the Kafue River flowing through the Kafue Flats (Zambia), a tropical river-floodplain system in the Zambezi River basin. During the flooding season, $>80 \%$ of the Kafue River water passed through the floodplain, mobilizing large quantities of OC and ON, which resulted in a net export of 69$119 \mathrm{~kg} \mathrm{OC} \mathrm{km}^{-2} \mathrm{~d}^{-1}$ and $3.8-4.7 \mathrm{~kg} \mathrm{ON} \mathrm{km}^{-2} \mathrm{~d}^{-1}, 80 \%$ of which was in the dissolved form. The elemental $\mathrm{C}: \mathrm{N}$ ratio of $\sim 20$, the comparatively high $\delta^{13} \mathrm{C}$ values of $-25 \%$ o to $-21 \%$, and its spectroscopic properties (excitation-emission matrices) showed that DOM in the river was mainly of terrestrial origin. Despite a threefold increase in OC loads due to inputs from the floodplain, the characteristics of the riverine DOM remained relatively constant along the sampled 410$\mathrm{km}$ river reach. This suggests that floodplain DOM displayed properties similar to those of DOM leaving the upstream reservoir and implied that the DOM produced in the reservoir was relatively short-lived. In contrast, the particulate fraction was ${ }^{13} \mathrm{C}$-depleted $(-29 \%$ ) and had a $\mathrm{C}: \mathrm{N}$ ratio of $\sim 8$, which indicated that POM originated from phytoplankton production in the reservoir and in the floodplain, rather than from plant debris or resuspended sediments. While the upstream dam had little effect on the DOM pool, terrestrial particles were retained, and POM from algal and microbial
\end{abstract}

sources was released to the river. A nitrogen mass balance over the $2200 \mathrm{~km}^{2}$ flooded area revealed an annual deficit of $15500-22100$ t N in the Kafue Flats. The $\mathrm{N}$ isotope budget suggests that these $\mathrm{N}$ losses are balanced by intense $\mathrm{N}$ fixation. Our study shows that the Kafue Flats are a significant local source of OC and ON to downstream ecosystems and illustrates how the composition of riverine OM can be altered by dams and floodplains in tropical catchments.

\section{Introduction}

Floodplains can act as major sources or sinks for riverine carbon $(\mathrm{C})$ and nitrogen $(\mathrm{N})$, regulating the organic matter $(\mathrm{OM})$ transport from headwaters to downstream systems such as lakes and oceans. Numerous studies in temperate floodplains have quantified their function as efficient particle and nutrient sinks (e.g. Noe and Hupp, 2009; Hoffmann et al., 2011; Olde Venterink et al., 2003), while only a few studies have examined tropical systems (e.g. McJannet et al., 2012). Despite the importance of wetlands in the global $\mathrm{C}$ cycle, the role of floodplains for riverine $\mathrm{C}$ storage, transformation and export has not been well constrained (Battin et al., 2009). This is particularly true for the large wetlands in the tropics, which are among the most productive and valuable ecosystems worldwide.

Previous studies have investigated the biogeochemistry of dissolved organic carbon (DOC) in different tropical riverfloodplain systems (e.g. Alin et al., 2008; Aufdenkampe et al., 2007; Spencer et al., 2010), and identified large 
differences in age, origin, chemical structure and bioavailability within the DOC pool and between DOC and particulate organic C (POC). While POC in forested catchments has frequently been associated with plant debris, the source allocation of DOC is more complex and often inconclusive (Tremblay and Benner, 2009). The organic $\mathrm{N}$ fraction, in particular the analysis of dissolved organic N (DON), however, has seldom been used as a means of dissolved OM (DOM) characterization in tropical systems, despite the fact that DON accounts for 50-90\% of total dissolved N (TDN), and generally high DON export from tropical catchments (Berman and Bronk, 2003; Wiegner et al., 2009).

Hydrological interaction between rivers and floodplains has been identified as a primary factor governing OM mobilization and nutrient dynamics in temperate systems (Hunsinger et al., 2010). In the tropical floodplains of the Amazon basin, river-floodplain exchange has been shown to affect particle distribution and storage (Aalto et al., 2003), cause shifts in the composition of riverine OM due to the injection of floodplain-derived OM to rivers (Richey et al., 1990), and foster in-stream mineralization of OM (Mayorga et al., 2005).

In this study we examined the changes in loading and quality of riverine $\mathrm{OC}$ and $\mathrm{ON}$ during passage through highly productive floodplains. We characterized POM and DOM in the Kafue Flats (Fig. 1a), a floodplain system along the Kafue River, the largest tributary of the Zambezi River in southern Africa. The hydrology of the Kafue River shows a distinct seasonality, with more than $80 \%$ of the river discharge during the wet season $\left(600-800 \mathrm{~m}^{3} \mathrm{~s}^{-1}\right)$ passing through the floodplain (Zurbrügg et al., 2012). For comparison, only $\sim 30 \%$ of the Amazon stream flow travels through floodplains (Richey et al., 1989). During the dry season, the discharge is rather constant and the exchange with the floodplain strongly reduced. Intense river-floodplain exchange exerts a strong influence on river biogeochemistry of the Kafue River, as evidenced by pronounced hypoxia over the last $150 \mathrm{~km}-$ long river reach dominated by lateral inflows from the inundated floodplain (Zurbrügg et al., 2012).

The case of the Kafue Flats illustrates how a pristine tropical floodplain system can be affected by water resources development. Two large dams built in the 1970s have altered the hydrological regime (Zurbrügg et al., 2012), and the flooding patterns in the Kafue Flats (Mumba and Thompson, 2005; Meier et al., 2010). The associated changes in downstream flooding modified the hydrological connectivity between river and floodplain, and could eventually affect the quality and fluxes of OM (Bouillon et al., 2009). Biogeochemical impacts of dam operation in this system have been addressed recently (Zurbrügg et al., 2012; Kunz et al., 2011) as part of an effort to quantify the effect of damming on fluvial ecosystems in the tropics.

The goals of this study were (1) to quantify retention or leaching and export of $\mathrm{OC}$ and $\mathrm{ON}$ from the floodplain to the river, and the net export from the Kafue Flats; (2) to de- termine source, quality and fate of the exported OM during the flooding and dry season; (3) describe how intense riverfloodplain exchange affects the sources of OM transported by the Kafue River; and (4) to explore changes in OM mobilization, transport, and quality that are related to dam operation. We hypothesized that intense river-floodplain exchange and the backflow from the floodplain carries large OM loads with terrestrial characteristics to the river and alter the composition of the riverine OM. In addition, we hypothesized that dam operation would affect the source and quality of OM in the downstream Kafue Flats.

\section{Methods}

\subsection{Study site - Kafue Flats}

The Kafue Flats are a floodplain system along the Kafue River in Zambia (Fig. 1a). The total area of the floodplain is $6500 \mathrm{~km}^{2}$, whereof up to $3300 \mathrm{~km}^{2}$ are seasonally inundated (Köck, personal communication). The annual flooding occurs from January to August and is caused by direct precipitation (November-April; mean $800 \mathrm{~mm}$ ), the peak flows of the Kafue River (up to $1900 \mathrm{~m}^{3} \mathrm{~s}^{-1}$; Fig. 1b), and seasonal tributaries, creating an extensive wetland area and rich wildlife habitat. The floodplain vegetation fringing the river channel consists of highly productive $\mathrm{C}_{4}$ grasses, with a net primary production of $800-2000 \mathrm{~g} \mathrm{C} \mathrm{m}^{-2} \mathrm{yr}^{-1}$, while water meadows with less productive $\mathrm{C}_{3}$ vegetation prevail in the more distant areas (Ellenbroek, 1987). During the dry season from June-October, river discharge drops to $<100 \mathrm{~m}^{3} \mathrm{~s}^{-1}$ (Fig. 1b) and the floodplain dries up almost completely. The land use in the immediate catchment is traditional, that is, small-scale cattle farming and fisheries, and large areas remain unutilized. Sugar cane plantations are located along the last 60 river-km, leaving large sections of the Kafue Flats relatively pristine.

The hydrology of the Kafue River $\left(Q_{\text {avg }} \sim 300 \mathrm{~m}^{3} \mathrm{~s}^{-1}\right)$ has been influenced by two large dams at Itezhi-Tezhi (ITT; closed in 1978) immediately upstream of the flats, and Kafue Gorge (closed in 1972), immediately downstream of the flats (Fig. 1c). At ITT dam, water is currently released to the floodplain via spillways, draining the reservoir's epilimnion. A recent study by Kunz et al. (2011) showed that ITT reservoir (with a hydraulic residence time of $\sim 0.7 \mathrm{yr}$ ) efficiently traps particles and removes $50 \%$ of $\mathrm{N}$ and $60 \%$ of $\mathrm{P}$ inputs from the Kafue River.

Intense hydrological exchange between river and floodplain has been identified as a major feature in the Kafue Flats (Zurbrügg et al., 2012). A constriction of the river channel forced $70 \%$ of the stream flow into the floodplain between 180 and $225 \mathrm{~km}$ downstream of ITT dam (Fig. 2). The backflow from the wetlands caused a seasonally recurring steep decline in dissolved oxygen (DO) concentration down to $<1 \mathrm{mg} \mathrm{l}^{-1}$ and low DO levels $\left(<2 \mathrm{mgl}^{-1}\right)$ along a $150-\mathrm{km}$ river reach. 

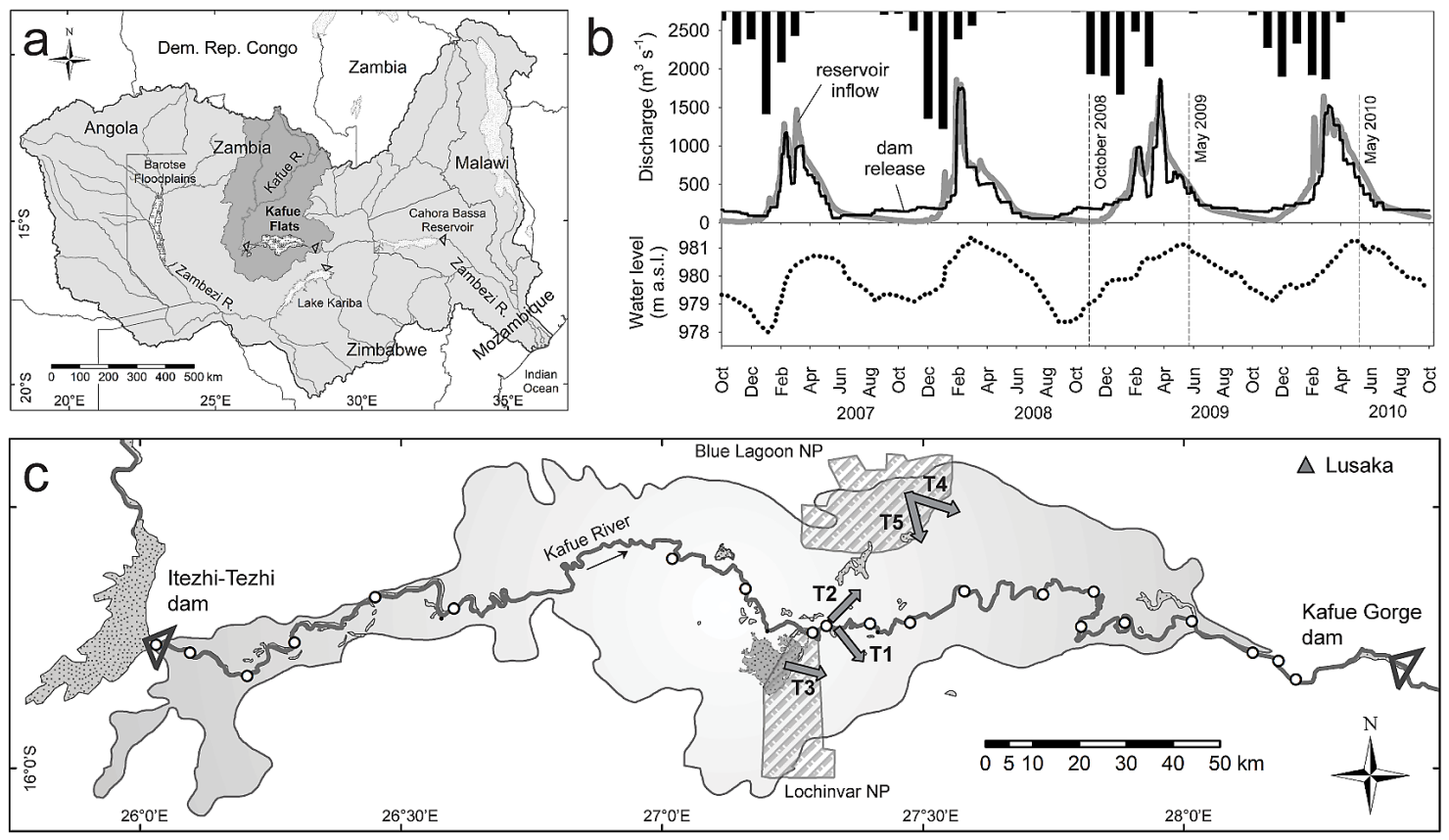

Fig. 1. (a) Kafue Flats in the Kafue River basin (dark shaded), a sub-basin of the Zambezi River basin (light gray). (b) The hydrograph from 2007-2010 shows the reservoir inflow (gray line), dam release (black line), rainfall (bars), and the water level in the middle of the floodplain (dotted line, lower panel). The three sampling campaigns are marked by vertical lines. (c) Map of the Kafue Flats. Dams are marked with triangles, white dots indicate sampling stations along the main channel, arrows T1-T5 depict transects into the floodplain.

The extent of river-floodplain exchange during inundation was quantified in a mixing model using natural tracers such as specific conductivity and $\delta^{18} \mathrm{O}-\mathrm{H}_{2} \mathrm{O}$ (stable oxygen isotope composition of water; Zurbrügg et al., 2012). The tracer levels in ITT reservoir and along transects into the floodplain served as end members to calculate the fractions of floodplain and reservoir water to the river discharge for the 410 $\mathrm{km}$ longitudinal transect (Fig. 2). Intense lateral exchange was observed after $\sim 230 \mathrm{~km}$, by monitoring the increasing contribution of floodplain water to river discharge (Fig. 2). As a net result, more than $80 \%$ of the water leaving the Kafue Flats had passed through the floodplain. A comparison of the 2008-2009 exchange regime with historical discharge data showed that the magnitude river-floodplain exchange has been reduced by $50 \%$ since the construction of the two dams in the 1970s (Zurbrügg et al., 2012). In addition, dam operation also changed the timing and extent of inundation in the Kafue Flats (Mumba and Thompson, 2005).

\subsection{Sampling campaigns}

After a pilot campaign in May 2008, three spatially intensive sampling campaigns were carried out during the dry season (October 2008), and the flooding seasons in May 2009 and May 2010 (Fig. 1b). Sampling was conducted along the Kafue River at $\sim 20 \mathrm{~km}$ resolution from downstream of the spillways at ITT dam $(0 \mathrm{~km})$ until the end of the floodplain $(410 \mathrm{~km}$; Fig. 1c). To characterize floodplain waters, addi-

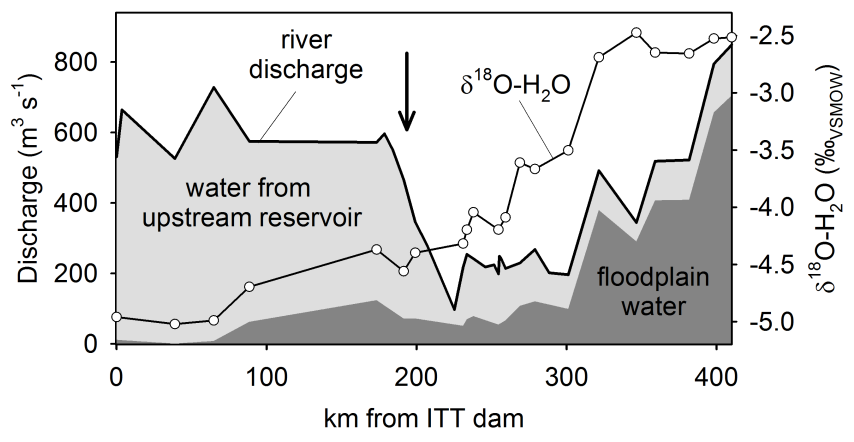

Fig. 2. Evidence of river-floodplain exchange in May 2010, indicated by an increasing proportion of floodplain-derived water (dark gray shading) to the river discharge (solid line) relative to water from the upstream reservoir (light gray shading). The contribution of floodplain water was calculated by a mixing model based on $\delta^{18} \mathrm{O}-\mathrm{H}_{2} \mathrm{O}$ along the river (full circles). For details see Zurbrügg et al. (2012). The arrow marks the steep decline in discharge (180$225 \mathrm{~km}$ ) caused by a constriction in the river channel.

tional samples were taken along $2-7 \mathrm{~km}$ transects perpendicular to the Kafue River into the floodplain (T1-T3), and from the wetland boundaries towards the floodplain in Blue Lagoon National Park (T4-T5; Fig. 1c) in May 2010. Water samples were pumped from mid-depth in the middle of the well-mixed river channel through hydrochloric acid $(\mathrm{HCl})$ and MilliQ-washed polyethylene and teflon tubing, using a 
peristaltic pump (Ejikelkamp, 12 VDC Standard). The tubing was flushed repeatedly before taking samples, and the contact time was minimized to avoid contamination. Samples for DOC and DON, and spectroscopic analyses were filtered in the field through $0.7 \mu \mathrm{m}$ glass fiber (GF) filters (Whatman) into glass bottles and LDPE bottles for DON. Samples for spectroscopic analyses were kept at $4{ }^{\circ} \mathrm{C}$ in the dark and analyzed within 3-4 weeks after sampling. Replicate measurements were done after different storage times after sampling and no effect of storage was detected. Water samples for elemental and isotope analyses were acidified to $\mathrm{pH} 2.5$ and frozen until further analysis. For POC and particulate N (PN) characterization, particles from $\sim 2 \mathrm{~L}$ of water were collected on $0.7 \mu \mathrm{m}$ GF filters (Whatman) and frozen until analysis. All sampling equipment was $2 \mathrm{M} \mathrm{HCl} /$ MilliQ-washed, glassware and filters were, in addition, pre-combusted $(6 \mathrm{~h}$ at $450{ }^{\circ} \mathrm{C}$ ). For comparative purposes, $\delta^{13} \mathrm{C}, \delta^{15} \mathrm{~N}$ and $\mathrm{C}$ and $\mathrm{N}$ contents were also analyzed in floodplain vegetation, soil $\mathrm{OM}$, river sediment, and dry deposition (see Supplement for details).

\subsection{Laboratory analyses}

\subsubsection{Concentrations and stable isotopic composition of DOC, POC and PN}

DOC concentration was measured on a Shimadzu 5050 TOC analyzer. For POC and PN concentration and $\mathrm{C}$ and $\mathrm{N}$ isotope measurements $\left(\delta^{13} \mathrm{C}-\mathrm{POC}\right.$ and $\delta^{15} \mathrm{~N}-\mathrm{PN}$, respectively), GF filters were dried $\left(3 \mathrm{~h}\right.$ at $\left.40^{\circ} \mathrm{C}\right)$, and cut into subsamples. POM samples were not acidified because the sediments of ITT reservoir contained only negligible amounts of inorganic carbon (Kunz et al., 2011) and the epilimnion was undersaturated with respect to calcium carbonate $\left(\mathrm{CaCO}_{3}\right.$; data not shown). POM aliquots were enclosed in tin capsules and measured on a FlashEA 1112 coupled to a DeltaV Adantage Continuous-Flow Isotope Ratio Mass Spectrometer (FlashEA-CF-IRMS; ThermoFinnigan). In-house ethylenediaminetetraacetic acid (EDTA; $\delta^{13} \mathrm{C}=-30.25 \%$ ovPDB $; \quad \delta^{15} \mathrm{~N}=-1.1 \%$ a air $)$ and ammonium oxalate standards $\left({ }^{13} \mathrm{C}=-17.02 \%\right.$ ovPDB; $\delta^{15} \mathrm{~N}=+32.7 \%$ oair $)$ were used for calibration, with a precision of $\pm 0.1 \%$ ovPDB for $\delta^{13} \mathrm{C}$ and $\pm 0.2 \%$ oair for $\delta^{15} \mathrm{~N}$. The isotopic ratios are reported using the delta notation, that is, $\delta^{13} \mathrm{C}$ or $\delta^{15} \mathrm{~N}=\left(R_{\text {sample }}-1\right) \times R_{\text {standard }} \times 1000 \%$ o, where $R$ is the isotopic ratio $\left({ }^{13} \mathrm{C}:{ }^{12} \mathrm{C}\right.$ or $\left.{ }^{15} \mathrm{~N}:{ }^{14} \mathrm{~N}\right)$ of the sample $\left(R_{\text {sample }}\right)$ and the standards $\left(R_{\text {standard }}\right)$, i.e. Vienna Pee Dee Belemnite (VPDB) for $\mathrm{C}$ and atmospheric $\mathrm{N}_{2}$ for $\mathrm{N}$.

For the C-isotope analysis of DOC $\left(\delta^{13} \mathrm{C}\right.$-DOC $), 1 \mathrm{ml}$ of $5 \mathrm{~g} \mathrm{l}^{-1}$ high-purity, precombusted potassium sulfate $\left(\mathrm{K}_{2} \mathrm{SO}_{4}\right)$ was added to $40 \mathrm{ml}$ of sample and the acidic samples were purged for $2 \mathrm{~min}$ with argon to remove inorganic $\mathrm{C}(\mathrm{HCl}$ had been added in the field), refrozen and freeze-dried (Schwendenmann and Veldkamp, 2005). The precipitate was measured on the same FlashEA-CF-IRMS using IAEA-CH6 su- crose $\left(\delta^{13} \mathrm{C}=-10.45 \%\right.$ ovPDB $)$, EDTA and ammonium oxalate as standards at an analytical precision of $\pm 0.1 \%$ ovPDB . The analytical precision is based on replicate measurements of untreated standards of sucrose $(n=7)$ and ammonium oxalate $(n=7)$, and standards that were processed as samples ( $n=6$ and $n=8$, respectively).

\subsubsection{Concentrations of DIN and DON, and $\delta^{15} \mathrm{~N}-\mathrm{TDN}$}

For dissolved inorganic $\mathrm{N}$ (DIN), ammonium $\left(\mathrm{NH}_{4}^{+}\right)$and nitrite $\left(\mathrm{NO}_{2}^{-}\right)$were measured using standard colorimetric techniques. The sum of nitrate $\left(\mathrm{NO}_{3}^{-}\right)$and $\mathrm{NO}_{2}^{-}$was determined by reduction to nitrous oxide (Braman and Hendrix, 1989) in an acidic vanadium (III) solution in an Antek 745 preparation module followed by chemoluminescence detection (Antek 9000), and $\mathrm{NO}_{3}^{-}$was calculated by difference.

TDN was measured according to Solórzano and Sharp (1980) and Bronk et al. (2000) by oxidizing $12 \mathrm{ml}$ of filtered sample to $\mathrm{NO}_{3}^{-}$with $2 \mathrm{ml}$ of persulfate oxidizing reagent (POR), which consisted of $6 \mathrm{~g}$ potassium peroxydisulfate $\left(\mathrm{K}_{2} \mathrm{~S}_{2} \mathrm{O}_{8}\right)$ and $6 \mathrm{~g}$ sodium hydroxide $(\mathrm{NaOH}$; both ACS-grade) per $100 \mathrm{ml}$ MilliQ water (Knapp et al., 2005). In order to reduce the nitrogen blank of POR, the peroxydisulfate salt was recrystallized 3-5 times according to Grasshoff et al. (1999) and stored under argon atmosphere. Samples with POR were autoclaved in $30 \mathrm{ml}$ Pyrex vials (acid washed, precombusted, teflon-lined lids) for $55 \mathrm{~min}$ and the $\mathrm{NO}_{3}^{-}$concentration was measured as described above. IAEA-N2 (ammonium sulfate $\left(\mathrm{NH}_{4}\right)_{2} \mathrm{SO}_{4} ;+20.3 \% o_{\text {air }}$ ), USGS-41 (L-glutamic acid; $\left.+47.6 \% o_{\text {air }}\right)$, urea $\left(+0.24 \% o_{\text {air }}\right)$, and EDTA were used as processing and isotopic standards, and were oxidized with the samples over the expected concentration range (Fig. S1, Supplement). The oxidation yield was $95-106 \%$ after blank correction. Duplicates of pure POR solution were oxidized with every run to determine the contribution of POR to the $\mathrm{N}$ blank. The POR blank contribution was generally $0.5 \pm 0.3 \mu \mathrm{M}$ per sample, which is equal to $\sim 3 \%$ of the sample TDN. DON concentrations were calculated as $\mathrm{DON}=\mathrm{TDN}-\mathrm{NO}_{3}^{-}-\mathrm{NO}_{2}^{-}-\mathrm{NH}_{4}^{+}$.

The $\delta^{15} \mathrm{~N}$ ratio of TDN-derived $\mathrm{NO}_{3}^{-}\left(\delta^{15} \mathrm{~N}\right.$-TDN) was measured according to Knapp et al. (2005) and Bourbonnais et al. (2009), combining persulfate oxidation and the denitrifier method (Casciotti et al., 2002; Sigman et al., 2001) where $\mathrm{NO}_{3}^{-}$is bacterially converted to $\mathrm{N}_{2} \mathrm{O}$. After microbial reduction of $\mathrm{NO}_{3}^{-}, \mathrm{N}_{2} \mathrm{O}$ was measured on a modified GasBench II with a GC PAL autosampler coupled to a Delta Plus XP Continuous Flow IRMS (all instruments ThermoFinnigan). IAEA-NO3 $\left(+4.7 \% o_{\text {air }}\right)$ and in-house UBN1 $\left(+14.2 \% o_{\text {air }}\right)$ were used as $\delta^{15} \mathrm{~N}^{-\mathrm{NO}_{3}^{-}}$standards. DON dominated TDN in all samples (generally $>94 \%$ ), therefore, $\delta^{15} \mathrm{~N}-\mathrm{TDN}$ can be considered a reasonable approximation to $\delta^{15} \mathrm{~N}-\mathrm{DON}$ and no large changes from $\mathrm{NO}_{3}^{-}$in $\delta^{15} \mathrm{~N}-\mathrm{TDN}$ were expected. 


\subsubsection{Concentrations of total suspended solids}

Total suspended solids (TSS) were measured in October 2008 and May 2009 by gravimetry, that is, weighing $47 \mathrm{~mm}$ pre-combusted $0.7 \mu \mathrm{m}$ GF filters (Whatman) before and after filtration of $\sim 21$ of water sample and subsequent drying $(3 \mathrm{~h}$ at $40^{\circ} \mathrm{C}$ ).

\subsubsection{Spectroscopic analyses}

To constrain the source and chemical character of DOM we measured specific UV absorption at $254 \mathrm{~nm}\left(\mathrm{SUVA}_{254}\right)$, which is a measure of the aromaticity of the DOM (Weishaar et al., 2003). UV absorption from 200-700 $\mathrm{nm}$ was measured in a $1 \mathrm{~cm}$ quartz cuvette using a UV-VIS spectrophotometer (Varian Cary 100Bio) and SUVA 254 was calculated as

$\mathrm{SUVA}_{254}=\frac{\mathrm{Abs}_{254}}{[\mathrm{DOC}]}\left[\mathrm{lmg}^{-1} \mathrm{~m}^{-1}\right]$,

whereby $\mathrm{Abs}_{254}$ is the absorption measured at $254 \mathrm{~nm}$ and [DOC] is the DOC concentration. Excitation-emission matrices (EEMs; Coble, 1996; McKnight et al., 2001) were obtained for each of the 45 filtered whole water samples from May 2010 over an excitation range from 240 to $450 \mathrm{~nm}$ in $5 \mathrm{~nm}$ increments and an emission range from 320 to $550 \mathrm{~nm}$ in $2 \mathrm{~nm}$ increments on a Fluoromax-4 spectrofluorometer (Horiba Jobin Yvon). All matrices were corrected for the inner-filter effect, using measured UV absorbance (Lakowicz, 2006), for lamp decay (Stedmon et al., 2003), and normalized by the Raman peak area. Parallel factor analysis (PARAFAC) was used to identify the underlying fluorescence components following the procedures of Stedmon et al. (2003) and Stedmon and Bro (2008). A series of PARAFAC models with two to eight components were fitted to the data and we found that a four-component model gave the best representation of the EEMs' fluorescence signal. More details on PARAFAC modeling are given in the Supplement.

In order to characterize the origin of DOM, the fluorescence index (FI) was calculated as:

$\mathrm{FI}=\frac{\mathrm{Em}_{470}}{\mathrm{Em}_{520}}$.

$\mathrm{Em}_{470}$ and $\mathrm{Em}_{520}$ are the emission intensities at wavelengths of $470 \mathrm{~nm}$ and $520 \mathrm{~nm}$, respectively, at an excitation wavelength of $370 \mathrm{~nm}$ (Cory et al., 2010). The FI was originally developed to distinguish fulvic acids from "terrestrial" (e.g. from decomposition and leaching of plant and soil organic matter) and "microbial" sources (autochthonous; e.g. from extracellular release and leachate of algae and bacteria; McKnight et al., 2001) and has widely been applied for bulk DOM samples (e.g. Johnson et al., 2011; Mladenov et al., 2005; Miller and McKnight, 2010). The range of FI is confined by end member fulvic acids from terrestrially dominated (river draining a swamp) and microbially dominated sources (lakes in the Antarctica). The end member values are $\sim 1.2$ for terrestrial and, $\sim 1.6$ for the microbial sources, whereby values of $>1.4$ indicate rather microbial and $<1.4$ mainly terrestrial origin (Cory et al., 2010).

\subsection{Statistical analyses}

Correlations between normally distributed parameters were determined by linear regression, and by Spearman's correlations for non-normally distributed data. To evaluate differences between pooled data, we used ANOVA if normally distributed, otherwise we used non-parametric Kruskal-Wallis tests, both at a critical level of 0.05 . Averaged data are given as mean \pm SD. Statistical analyses were done with SigmaPlot 11. The full concentration and stable isotope data set is available as an electronic supplement.

\section{Results}

\subsection{Organic carbon and nitrogen concentrations along the Kafue River}

Longitudinal profiles of dissolved and particulate organic matter revealed significant differences between the two flooding season campaigns in May 2009 and May 2010 compared to the data set from the dry season in October 2008 (Fig. 3). Wet season DOC increased from $\sim 250 \mu \mathrm{M}$ immediately downstream of ITT dam $(0 \mathrm{~km})$ to $\sim 400 \mu \mathrm{M}$ at end of the floodplain $(410 \mathrm{~km}$; Fig. 3a). Most of the DOC increase occurred after $230 \mathrm{~km}$, where a large influx of floodplainderived water began entering the river (Fig. 2). Dry season DOC concentrations remained relatively constant at $280 \pm$ $50 \mu \mathrm{M}$ along the river reach, with the exception of lower concentrations at $240 \mathrm{~km}$ and $270 \mathrm{~km}$.

Flooding season DON concentrations showed a similar twofold increase, from $\sim 10 \mu \mathrm{M}$ at the dam site to maximum concentrations of $\sim 20 \mu \mathrm{M}$ at $410 \mathrm{~km}$. In the dry season, DON was found at fairly constant concentrations of $14 \pm 1.2 \mu \mathrm{M}$. For all three campaigns, ON was the dominant form of N, representing 93-97\% of total $\mathrm{N}$ while DIN, mainly in form of $\mathrm{NO}_{3}^{-}$and $\mathrm{NH}_{4}^{+}$, was generally $<1.5 \mu \mathrm{M}$ (data not shown). As a logic consequence of the similar increase of the DOC and DON concentrations for all three campaigns, the molar DOC:DON ratio remained relatively invariant along the river (May 2010: $19.7 \pm 2.4$; May 2009: 23.2 \pm 2.3 ; October 2008: $19.8 \pm 3.5$; Fig. 3a). In May 2010, DOC tended to be higher in the inundated floodplain than at the adjacent river stations, reaching up to $600 \mu \mathrm{M}$, while the DON concentrations were comparable to those measured in the river (Fig. 3a).

In contrast to the dissolved OM fraction, flooding season POC and PN concentrations were highest over the first $90 \mathrm{~km}$ after the dam (Fig. 3b), and decreased by factor of 2-3 between 200 and $300 \mathrm{~km}$ before rebounding towards the end of the Kafue Flats. Maximum concentrations were 40-65 $\mu \mathrm{M}$ 
for POC and $6.6 \mu \mathrm{M}$ for PN, respectively. For the dry season, pronounced peaks to $130 \mu \mathrm{M}$ POC and $13 \mu \mathrm{M}$ PN were evident between 200 and $300 \mathrm{~km}$ (Fig. 3b), while for the remaining reaches the concentrations of both parameters were comparable to values observed during flooding. As observed for the dissolved fraction, the molar ratio of POC and PN was uniform during the flooding period (May 2010: 7.9 \pm 0.9 ; May 2009: $8.6 \pm 0.7)$. For the dry season, POC: PN was elevated at the dam site but decreased to the levels found in May when passing the Kafue Flats (Fig. 3b).

TSS measurements from May 2009 and October 2008 generally followed the POC and PN concentration data (Fig. 3c). However, for both campaigns, the $\mathrm{C}$ and $\mathrm{N}$ content of the particles revealed that particles leaving the ITT reservoir were highly enriched in C (36-42 wt \%) and N (4.0-4.7 wt \%) relative to the downstream reaches, but $\mathrm{C}$ and $\mathrm{N}$ contents increased again between $200-300 \mathrm{~km}$.

\subsection{Carbon and nitrogen stable isotopes}

$\delta^{13} \mathrm{C}$-DOC values in the river were confined to a narrow range of $-21.0 \%$ to $-24.7 \%$ during all three sampling campaigns (Fig. 4). Nonetheless, some systematic variations were evident. During the May 2010 campaign, $\delta^{13} \mathrm{C}$ DOC exhibited a distinct increase from $-23.9 \%$ to $-21.7 \%$ o over the first $90 \mathrm{~km}$, and during both flooding season campaigns $\delta^{13} \mathrm{C}$-DOC decreased by $2.5 \%$ after $250 \mathrm{~km}$. Along the floodplain transects, ${ }^{13} \mathrm{C}$-enrichment in DOC tended to co-occur with high DOC concentrations, mostly in the more distant areas from the river channel. During the dry season, $\delta^{13} \mathrm{C}$-DOC did not show any systematic variation along the river channel and the negative peaks corresponded to the DOC concentration minima.

Across all sampling campaigns, $\mathrm{POC}$ at the river stations was systematically depleted in ${ }^{13} \mathrm{C}$ relative to the corresponding DOC (mean difference $=5.1 \pm 1.7 \%$; Fig. 4). During both flooding seasons, $\delta^{13} \mathrm{C}$-POC increased by $\sim 2.5 \%$ over the first $100 \mathrm{~km}$ downstream of ITT dam. The $\delta^{13} \mathrm{C}$-POC of floodplain samples varied substantially, covering a range of $-33.7 \%$ to $-23.4 \%$. In the dry season, $\delta^{13} \mathrm{C}$-POC initially remained constant at $-26 \%$, that is, enriched by $>1 \%$ relative to the co-located flooding season data. After $250 \mathrm{~km}$, $\delta^{13} \mathrm{C}$-POC sharply declined to almost $-30 \%$ which essentially is the ${ }^{13} \mathrm{C}$ signature of the POC leaving the Kafue Flats. $\delta^{15} \mathrm{~N}-\mathrm{TDN}$ values during the May 2010 and May 2009 campaigns exhibited limited variability along the river ( $2.1 \pm$ $0.4 \%$ and $1.4 \pm 0.5 \%$, respectively), as well as small differences between river and adjacent floodplain stations (Fig. 4). Dry season $\delta^{15} \mathrm{~N}$-TDN was characterized by a $3 \%$ increase over the first $65 \mathrm{~km}$ after the dam followed by a net decline of $\delta^{15} \mathrm{~N}$-TDN to $2.5 \%$ at the end of the floodplain. For the particulate fraction, $\delta^{15} \mathrm{~N}-\mathrm{PN}$ at ITT dam in May 2010 and 2009 was elevated by $\sim 2 \%$ relative to $\delta^{15} \mathrm{~N}$-TDN, and gradually approximated values comparable to $\delta^{15} \mathrm{~N}$-TDN further downstream (Fig. 4). Floodplain $\delta^{15} \mathrm{~N}-\mathrm{PN}$ in May $2010 \mathrm{cov}$ -
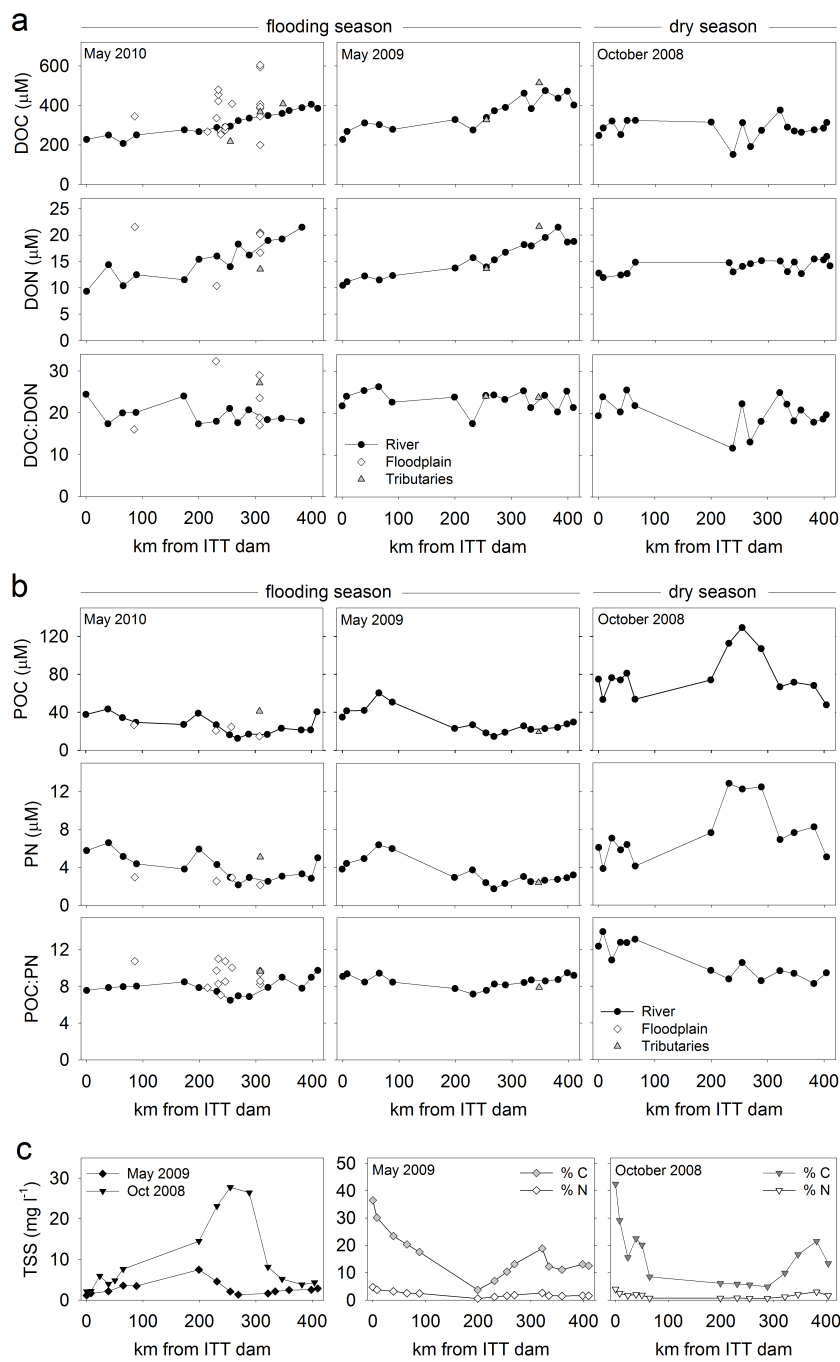

Fig. 3. (a) Concentrations of DOC and DON, and molar DOC : DON ratio, (b) concentrations of POC and PN, and molar POC : PN ratio for the flooding season (May 2010 and May 2009), and the dry season (October 2008) along the Kafue River channel (black dots and lines), at floodplain stations (empty diamonds) and tributaries (gray triangles). (c) TSS concentration and C and N content of the particles in the Kafue River for May 2009 and October 2008.

ered a considerably wider range than observed in river samples $\left(0.3 \%\right.$ o to $5.7 \%$ ) . High variation in $\delta^{15} \mathrm{~N}-\mathrm{PN}$ was also measured in the dry season, however, without obvious trend.

\subsection{Spectroscopic analyses of dissolved organic matter}

SUVA $_{254}$ was $3.5 \pm 0.31 \mathrm{mg}^{-1} \mathrm{~m}^{-1}$ (Fig. 5a) and did not change significantly along the river $(P=0.077)$, remaining unaffected by emerging river-floodplain exchange after $230 \mathrm{~km}$. Floodplain and tributary samples showed smaller but more variable values than the adjacent river reach. Similar to $\mathrm{SUVA}_{254}$, FI values along the main channel fell in 


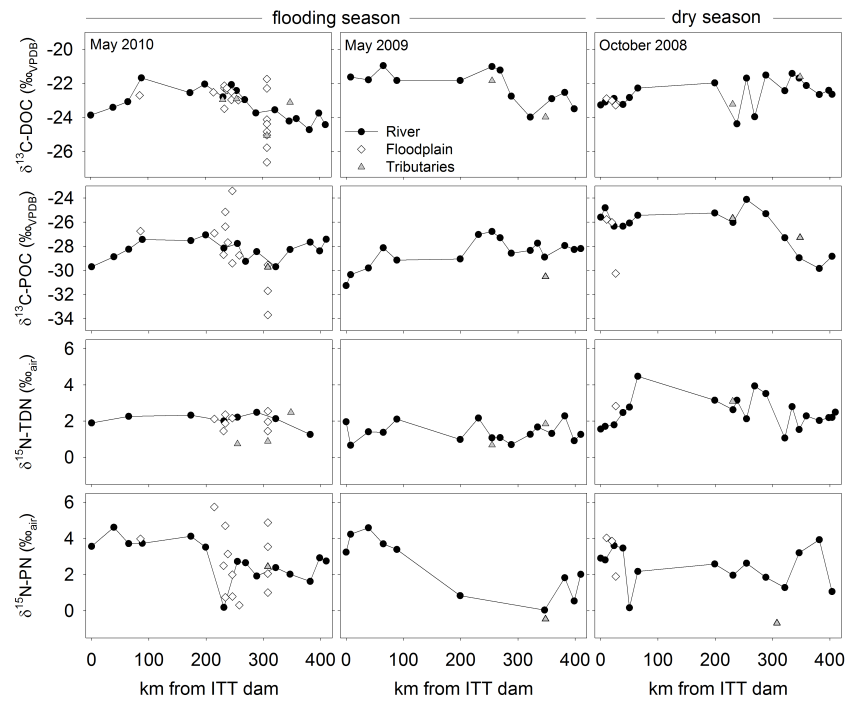

Fig. 4. Stable isotope signatures of dissolved and particulate organic carbon and nitrogen for the flooding seasons and dry season (symbols as indicated in Fig. 3).

a very narrow range between 1.42 and 1.47 and exhibited only minor, non-significant $(P=0.117)$ variation along the river (Fig. 5b). The EEMs showed a high degree of similarity among the stations along the river (Fig. 6a) and floodplain transects (Fig. 6b). Two main fluorescence peaks were detected at excitation/emission wavelengths of $345 / 440 \mathrm{~nm}$, and $240 / 430 \mathrm{~nm}$. These peaks are common features in natural DOM and have been named Peak A and Peak C (Coble, 1996), respectively.

\section{Discussion}

\subsection{Net export of organic matter from the Kafue Flats}

The Kafue River's channel morphology is conducive to intense exchange with the floodplain, yet this exchange is highly variable along the river (Fig. 2). During high flows, a large fraction of the stream flow was diverted into the floodplain between 180 and $225 \mathrm{~km}$, while downstream of the $300 \mathrm{~km}$ mark, water returned from the floodplain into the river, resulting in a $\sim$ fourfold discharge increase (Fig. 2). The average water residence time on the floodplain of $\sim 2$ months was deduced from the evaporative signal of water isotopes (Zurbrügg et al., 2012). Most of the discharge and the chemical loads of the lower Kafue River in May 2010 and May 2009 originated in, or passed through, the floodplain. Comparable levels of exchange occur every year when flow rates substantially exceed $\sim 200-300 \mathrm{~m}^{3} \mathrm{~s}^{-1}$ (December-July; Zurbrügg et al., 2012). During low-flow periods (August-November), the exchange with the floodplain was substantially reduced.
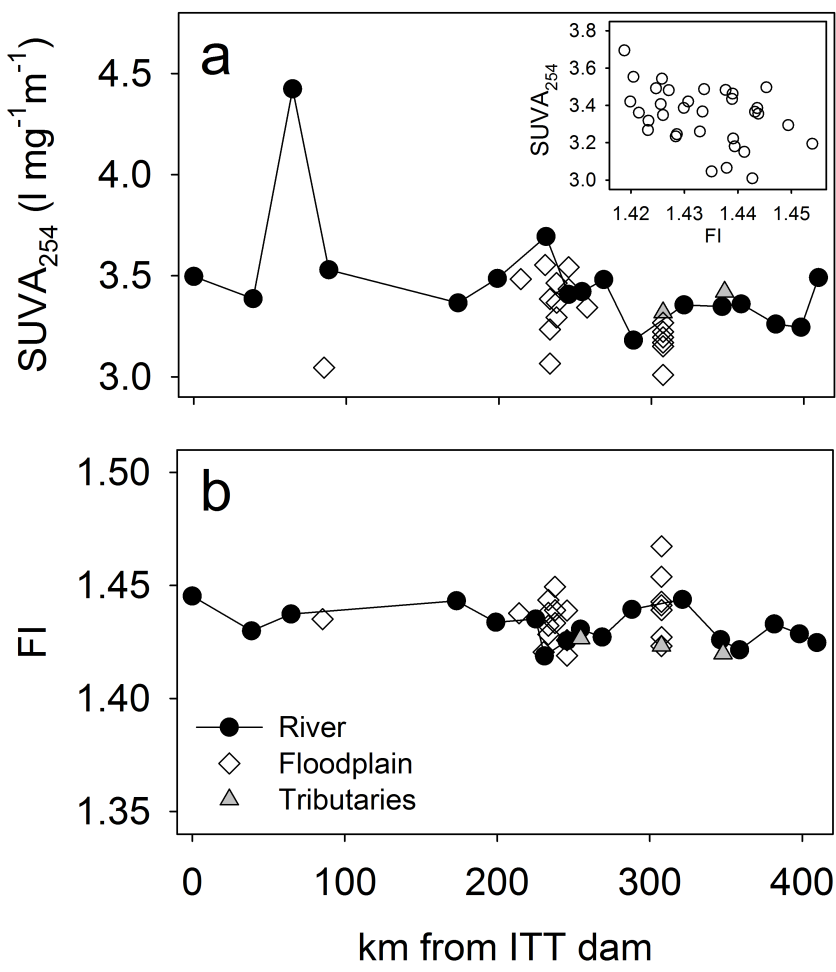

Fig. 5. (a) Specific UV absorption at $254 \mathrm{~nm}\left(\mathrm{SUVA}_{254}\right)$, and (b) fluorescence index (FI) along the river (black circles), in the floodplain (empty diamonds), and in tributaries (gray triangles) in May 2010. The insert in (a) shows the negative correlation of the pooled $\mathrm{SUVA}_{254}$ and FI data $(P<0.001)$. Samples with $\mathrm{SUVA}_{254}$ $>4.01 \mathrm{mg}^{-1} \mathrm{~m}^{-1}$ were removed for clarity.

We combined discharge measurements with concentration data to quantify mass loads of $\mathrm{OC}$ and $\mathrm{ON}$ along the river (Fig. 7; Table 1). In May 2010, the minimum discharge and minimum DOC and DON loads were observed at $\sim 230 \mathrm{~km}$ (Fig. 2), after $\sim 85 \%$ of the flow and loads had been forced into the floodplain (Fig. 7). Downstream of $230 \mathrm{~km}$, discharge and concentrations of dissolved organic matter increased, resulting in a threefold increase in loading (Table 1). As DOC and DON mass loads at $410 \mathrm{~km}$ were 2.7 and 2.3 times larger than at the dam, and some of the dissolved organic matter entering the floodplain may have been metabolized before reentering the river, a minimum of $82 \%$ of DOC and $75 \%$ of DON in the river originated from the floodplain. Load patterns in May 2009 were, overall, similar to those in May 2010, indicating that the large export pulses of DOC and DON from the Kafue Flats are a recurring seasonal phenomenon (Fig. 7). During the flooding period, the Kafue Flats were a net source of $108-214 \mathrm{tDOC} \mathrm{d}^{-1}$ and 6.0 $7.6 \mathrm{tDON} \mathrm{d}^{-1}$. This stands in contrast to the dry season when loads were reduced in general, and decreased along the river and when the Kafue Flats acted as net sink for dissolved organic matter. 

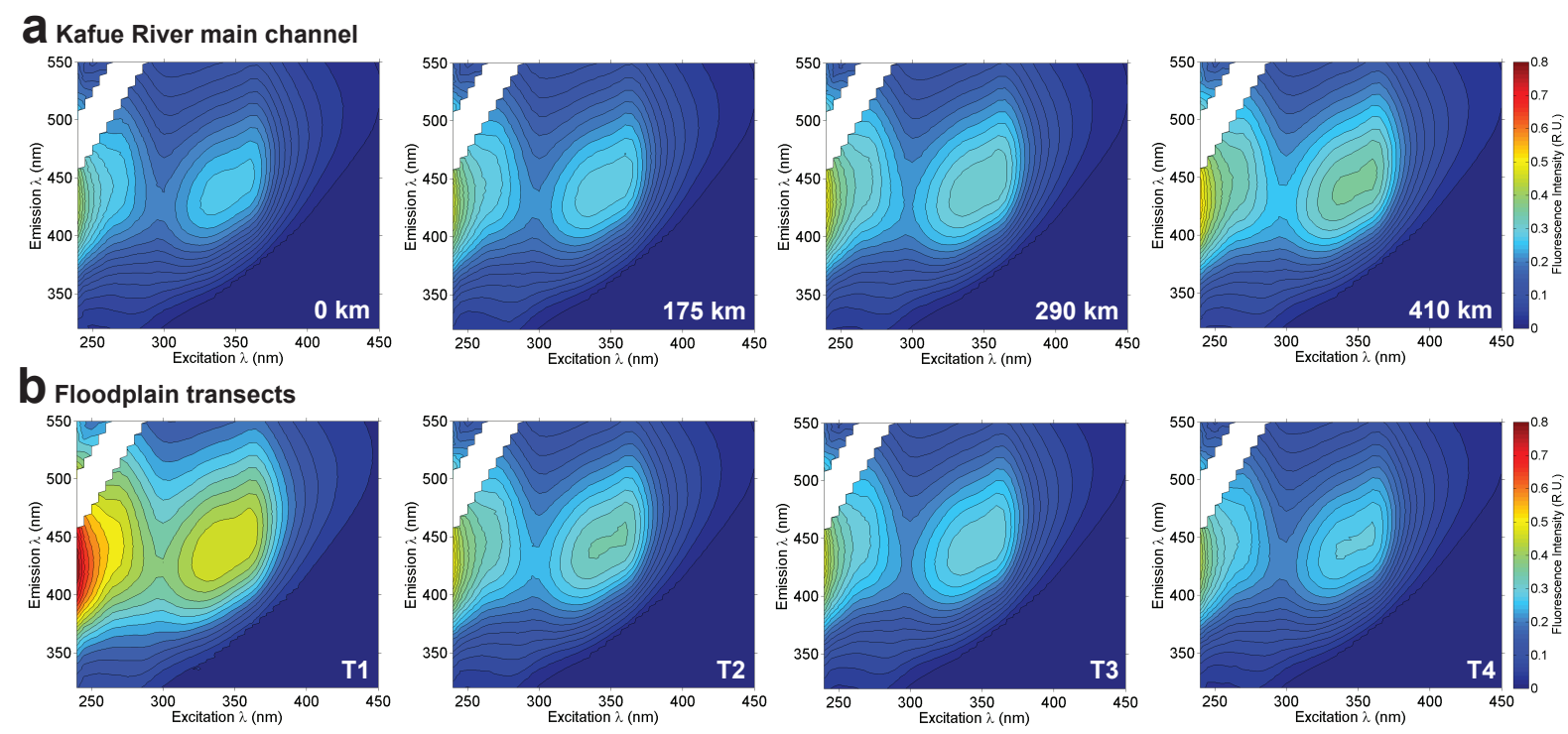

Fig. 6. Excitation-emission matrices (EEMs) for (a) four river samples indicated with distance from ITT dam, and (b) four floodplain samples along different floodplain transects. The two main fluorescence peaks are at excitation/emission wavelengths of $240 / 430 \mathrm{~nm}$ and $345 / 440 \mathrm{~nm}$, and have been named by Coble (1996) as Peak A and Peak C, respectively.

In contrast to the clear pattern of dissolved organic matter, the Kafue Flats were a net POM source only in May 2010, not in 2009. During inundation, the contribution of POC to the total OC declined threefold along the flow path from $\sim 15 \%$ to $\sim 5 \%$, and the PN fraction of total $\mathrm{N}$ from $\sim 30 \%$ to $\sim 10 \%$ (Fig. S2, Supplement). Concentration and load data show that some fraction of POM must have been deposited or degraded during the transit through the inundated floodplain. The floodplain had no net effect on the particle transport during the dry season, as the Kafue River was flowing through the flats with little floodplain interaction. The short travel times of 1.5 weeks along the river (average velocity of $\sim 0.5 \mathrm{~m} \mathrm{~s}^{-1}$ ) and relatively constant flows for several weeks around the sampling time period (Zurbrügg et al., 2012) allowed for a comparison of upstream and downstream loads. Strictly speaking, our results represent "snapshots" in time, which may not represent the average annual conditions. However, results from a bi-monthly sampling campaign that was carried out over one year at several stations along the river indicate a net export of OM predominating for several months. Integrated over an annual cycle, net exports from the Kafue Flats were estimated as $\sim 60000 \mathrm{t} \mathrm{OC} \mathrm{yr}^{-1}$ and $\sim 1800 \mathrm{t} \mathrm{ON} \mathrm{yr}^{-1}$, respectively (Wamulume et al., 2011).

The sources and sinks of a floodplain can be compared among different systems by scaling the fluxes to the active area. We assumed that the $\mathrm{OC}$ and $\mathrm{ON}$ export resulted from the total inundated area at a given time and used the inundation model of Meier et al. (2010) to retrieve flooded areas and calculate area-specific export rates (or yields). The monthly mean flooded surfaces for May 2010, May 2009
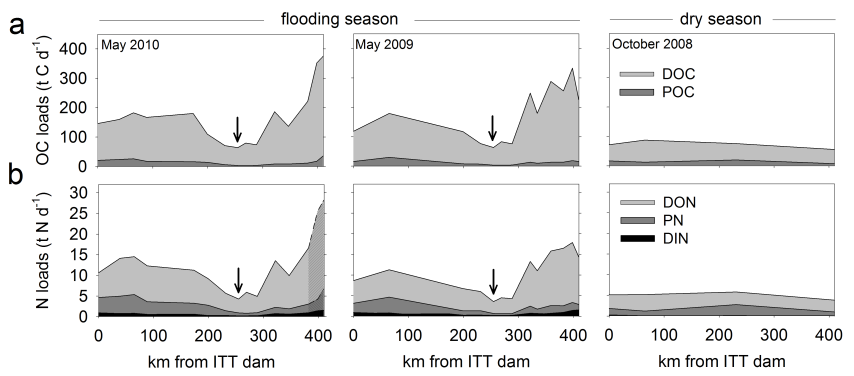

Fig. 7. Organic carbon (a) and nitrogen (b) loads ( $\mathrm{C}$ or N d$\left.^{-1}\right)$ calculated as discharge $\times$ concentration for the flooding and dry season. For the hatched areas in May 2010, N loads were calculated with extrapolated concentrations using the regression between DOC and DON ( $\rho=0.901, P<0.001)$, due to missing DON data. Arrows indicate the discharge minimum due to a channel constriction from Zurbrügg et al. (2012).

and October 2008 were $1930 \mathrm{~km}^{2}, 1560 \mathrm{~km}^{2}$ and $270 \mathrm{~km}^{2}$ (Köck, personal communication). Flooding in the dry season was restricted to the actual river channel and the permanently flooded areas after 320 river-km. Based on the net OC and $\mathrm{ON}$ export for the 2010 and 2009 flooding periods and the respective area, OC yields were 119 and $69 \mathrm{~kg} \mathrm{C} \mathrm{km}^{-2}$ $\mathrm{d}^{-1}$ (annual average 43 and $25 \mathrm{~g} \mathrm{C} \mathrm{m}^{-2} \mathrm{yr}^{-1}$ ) for May 2010 and 2009, respectively. The ON exports from the Kafue Flats were on the order of $6-9 \mathrm{t} \mathrm{N} \mathrm{d}^{-1}$, which corresponds to area normalized yields of $3.8-4.7 \mathrm{~kg} \mathrm{~N} \mathrm{~km}^{-2} \mathrm{~d}^{-1}$ (1.4$1.7 \mathrm{~g} \mathrm{~N} \mathrm{~m}^{-2} \mathrm{yr}^{-1}$ ) for May 2009 and 2010, respectively (Table 1). 
between the $\mathrm{C}: \mathrm{N}$ ratios of DOM and POM $(P<0.05)$ and between $\delta^{13} \mathrm{C}$ of DOC and POC across all campaigns (Fig. 8). This indicates that DOM and POM derived from distinctly different sources.

There are several lines of evidence indicating a planktonic source of particulate organic matter: POM had a substantially lower C:N elemental ratio $(\sim 8)$ than DOM $(\sim 21)$, soil OM and river sediments (both $\sim 20$; Table S1, Supplement). The relative elemental $\mathrm{N}$-enrichment and ${ }^{13} \mathrm{C}$-depletion suggest that POM along the river consisted mainly of phytoplankton sources (Hamilton and Lewis, 1992; Ellis et al., 2012). This finding is consistent with the high $\mathrm{C}$ content of the suspended material leaving the ITT reservoir (30-40 wt \% C; Fig. 3c). Profiles taken in ITT reservoir between May 2008 and June 2009 (Fig. S4, Supplement) showed epilimnetic $\delta^{13}$ C-POC signatures closely matching riverine $\mathrm{POC}$ in October 2008 and May 2009. Over an annual cycle, $\delta^{13} \mathrm{C}$-POC in the reservoir varied between -25 and $-30 \%$, indicating that some minor terrestrial contribution of fine POM cannot be excluded. In summary, however, there is strong evidence that the POM downstream of the dam originated mainly from the primary production of the reservoir.

By contrast, the composition of dissolved organic matter suggests primarily terrestrial sources: The consistently elevated DOC:DON (range 19-23; Fig. 3a) observed during all sampling campaigns and across all sites indicates an $\mathrm{N}$ poor DOM pool, indicating a terrestrial origin, given its elevated $\delta^{13} \mathrm{C}$ compatible with a mix of $\mathrm{C}_{3}$ vegetation and soil/sedimentary OM (Table S1, Supplement). DOM does not indicate any significant contribution from the $\mathrm{C}_{4}$ vegetation fringing the Kafue River (Ellenbroek, 1987), which has a distinct $C$ isotopic signature of $-13 \%$. Several studies in the Amazon River have documented high DOC:DON in refractory, degraded DOM from lowland reaches of Amazon tributaries (Aufdenkampe et al., 2007), dominated by fulvic and humic substances (Hedges et al., 2000), or soil-derived DOM (Bernardes et al., 2004). In some of the investigated systems like the Tana River in Kenya (Bouillon et al., 2007) or the Amazon (Raymond and Bauer, 2001), POC was enriched in ${ }^{13} \mathrm{C}$ relative to DOC, and DOC could thus originate from POC degradation. In the Kafue Flats this is unlikely, because of the consistently isotopically heavier DOC (Fig. 7).

Spectroscopic results supported the chemical findings that DOM was primarily of terrestrial origin, but they also revealed a microbially derived contribution. The $\mathrm{SUVA}_{254}$ values for the Kafue River of $\sim 3.51 \mathrm{mg}^{-1} \mathrm{~m}^{-1}$ are characteristic for humic substances of $\sim 25 \%$ aromaticity (Weishaar et al., 2003). Similarly, the two peaks detected in the EEMs, fall in the range of "humic acid-like" DOM (Peak A), and "fulvic acid-like" and "hydrophobic acid-like" DOM (Peak C), respectively (Chen et al., 2003). However, the FI of $\sim 1.43$ is a median between the terrestrial and microbial end members and indicates contributions of mixed sources to DOM (Cory et al., 2010). Because of the relative stability of terrestrial DOM, the FI is often negatively correlated with DOC con-
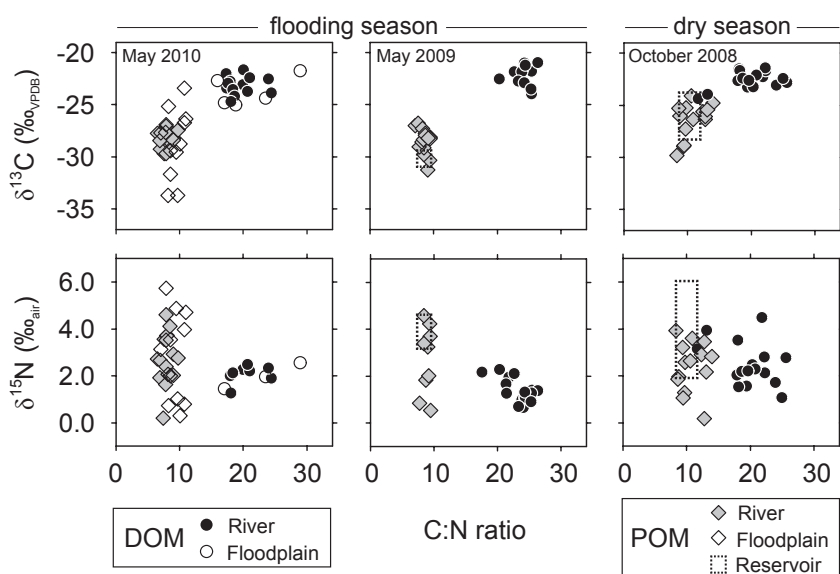

Fig. 8. $\delta^{13} \mathrm{C}$ and $\delta^{15} \mathrm{~N}$ values of dissolved and particulate organic matter, relative to their $\mathrm{C}: \mathrm{N}$ ratio. Dashed rectangles in May 2009 and October 2008 indicate the ranges measured in the epilimnion of the upstream ITT reservoir at the time of river sampling (Fig. S4, Supplement). Significant differences $(P<0.05)$ were found between $\mathrm{C}: \mathrm{N}$ ratios and $\delta^{13} \mathrm{C}$ of DOM and POM, throughout all sampling campaigns, but not for $\delta^{15} \mathrm{~N}$.

centration (Johnson et al., 2011; Petrone et al., 2011), but no significant correlation between FI or $\mathrm{SUVA}_{254}$ and DOC was found in the Kafue $(P>0.05)$. In other tropical systems, FI ranged from 1.21-1.41 on the Guayana Shield in Venezuela (Yamashita et al., 2010a) and 1.3-3.0 in the lower Amazon basin (Johnson et al., 2011), and in subtropical systems from 1.28-1.47 in the Everglades (Yamashita et al., 2010b) to 2.0 2.3 in the Yangtze River basin (Chen and Zheng, 2012). The microbial signal in the FI of the Kafue River DOM could be associated with the onset of microbial degradation of mobilized terrestrial OM after the peak flow (Johnson et al., 2011; Mladenov et al., 2005) or with the aquatic primary production in the floodplain.

The four components $\mathrm{C} 1-\mathrm{C} 4$ derived from the PARAFAC analysis provided additional evidence for terrestrial DOM with some minor microbial contribution. All components had been identified in previous studies (Fig. S6 and Table S2, Supplement) and were found characteristic for humic-like substances (Stedmon and Markager, 2005). The components $\mathrm{C} 1$ and $\mathrm{C} 3$ are exclusively from terrestrial sources while $\mathrm{C} 2$ and $\mathrm{C} 4$ can also have microbial origin. A detailed evaluation of components C2-C4 is given in Ishii and Boyer (2012).

Based on spectroscopic data (SUVA 254 , EEMs and FI), DOM sampled even directly after the dam spillways showed a strong terrestrial signature $\left(\mathrm{C}: \mathrm{N}, \delta^{13} \mathrm{C}, \delta^{15} \mathrm{~N}\right)$, which only moderately shifted with the addition of a large proportion of floodplain-derived DOM. This suggests that the largely refractory, terrestrial DOM pool leaving ITT reservoir originated from upstream wetlands and transited the reservoir basically unchanged. Such aged terrestrial OM was found to be a dominant source of $\mathrm{C}$ exported from the Ganges-Brahmaputra system (Galy and Eglinton, 2011). Studies in the Amazon have identified both a modern and an 
old (> $1000 \mathrm{yr}$ ) OM fraction (Raymond and Bauer, 2001), whereby young OM was found to be preferably mineralized (Mayorga et al., 2005). Large wetlands that are hydrologically connected to the Kafue River upstream of ITT reservoir (Lukanga and Busanga Swamps; total area $=4600 \mathrm{~km}^{2}$ ) are a potential source of this floodplain-like DOM.

In summary, DOM in the Kafue River was mainly of terrestrial origin with some microbial contribution, while POM had a distinct phytoplankton signature. Nevertheless, some variation in the chemical characteristics along the channel and between seasons was evident, which is discussed in the next section.

\subsection{Longitudinal and seasonal changes in organic matter characteristics}

Contrary to our hypotheses, OM quality indicators showed only small variation along the river, even along reaches of intense river-floodplain exchange and elevated $\mathrm{C}$ and $\mathrm{N}$ concentrations and loads. For POM, C:N ratios were rather invariant along the river even after the 3 to 10 -fold increase in POC and PN loads from floodplain contributions downstream of $300 \mathrm{~km}$ (Fig. 7), which caused some variation in the isotopic signatures of riverine POM. We propose that floodplain-derived POM and reservoir POM had simi$\operatorname{lar} \delta^{13} \mathrm{C}-\mathrm{POC}$ and $\mathrm{C}: \mathrm{N}$, and suggest that floodplain-derived POM was thus dominated by microbial sources, such as phytoplankton or periphyton from the floodplain. While the in-stream production was limited $\left(2-5 \mu \mathrm{g} 1^{-1}\right.$ chlorophyll $a$; Zurbrügg, unpublished), the consistently ${ }^{13} \mathrm{C}$-depleted POC in the river and along some floodplain transects (Fig. 4) suggest that floodplain primary production substantially contributed to riverine POM, e.g. from open lagoons on the floodplain, which can be sites of high primary production, even under low nutrient conditions (Cotner et al., 2006).

The small changes in $\mathrm{OM}$ characteristics along the river illustrated a complex interplay of terrestrial and microbial sources to the riverine OM pool, which has been observed in other studies (e.g. Tamooh et al., 2012). For example, $\delta^{13} \mathrm{C}-\mathrm{POC}$ and POC:PN between 200 and $300 \mathrm{~km}$ showed opposite trends for May 2009 and May 2010 (Fig. 4). Along this reach, the contribution of floodplain water was steadily rising (Fig. 2) and $\mathrm{C}$ and $\mathrm{N}$ loads, and the distinct increase in the C content of TSS in 2009 (Fig. 3a) imply that floodplain POM entered the river. Based on the $\delta^{13} \mathrm{C}-\mathrm{POC}$ and POC : PN, the floodplain inflows can be attributed to an increasing contribution of ${ }^{13} \mathrm{C}$-depleted and N-rich microbial POM in 2010, and ${ }^{13} \mathrm{C}$-enriched and $\mathrm{N}$-poor POM in 2009 which could originate from terrestrial sources, e.g. plant debris or eroded soils. During both flooding campaigns, $\delta^{13} \mathrm{C}$ POC increased by $2.5 \%$ over the first $90 \mathrm{~km}$, which could similarly be explained by erosion of ${ }^{13} \mathrm{C}$-enriched terrestrial matter of lower $\mathrm{C}$ content (Fig. 3c). Terrestrial inputs could also cause the concurrent $2 \%$ increase in $\delta^{13} \mathrm{C}$-DOC in May 2010. On the other hand, the decrease in $\delta^{13} \mathrm{C}$-DOC after $\sim 250 \mathrm{~km}$ during flood season (Fig. 4) requires an inflow of DOC with an average $\delta^{13} \mathrm{C}$ of $-30.2 \%$, based on a two endmember mixing calculation. This suggests a relative increase in the abundance of isotopically light DOM, produced from microbial sources.

Results from fluorescence spectroscopy revealed further changes in DOM composition along the river transect beginning at $\sim 230 \mathrm{~km}$. The PARAFAC component's peak fluorescence intensity $\left(\mathrm{F}_{\max }\right)$ sharply increased $(P<0.001)$ between 230 and $280 \mathrm{~km}$ for all four components (Fig. S7, Supplement). For each component, $F_{\max }$ was moderately to strongly correlated with DOC concentration $\left(R^{2}=0.68-\right.$ 0.87 ), with C3 ("terrestrial-humic") showing the highest correlation. To detect changes in the DOM fluorescence properties along the river, while correcting for the influence of varying DOC concentrations (Stedmon et al., 2003), we present the $\mathrm{F}_{\max }$ ratios of $\mathrm{C} 1, \mathrm{C} 2$ and $\mathrm{C} 4$ relative to $\mathrm{C} 3$ (Fig. 9). The sharp decrease in $\mathrm{C} 2$ after $230 \mathrm{~km}$ coincides with the decline in DO (Zurbrügg et al., 2012), which implies that C2-type DOM is preferentially degraded in the floodplain. Along the floodplain transects, $\mathrm{C} 1$ and $\mathrm{C} 4$ increased with increasing distance from the river or the shore into the floodplain (Fig. S9, supplement), indicating higher abundance or production of DOM with C1- and C4-like fluorophores in the floodplain.

More pronounced differences in the $\mathrm{OM}$ characteristics than along the longitudinal sampling transects were detected between wet and dry seasons. The absence of lateral exchange during the dry season was evident as relatively constant DOC and DON concentrations and loads (Fig.7). The differences between wet and dry season $\delta^{13} \mathrm{C}$-POC were consistent with the POM reservoir profiles (Fig. S4, Supplement). The marked peak in POC, PN and TSS concentrations between $200 \mathrm{~km}$ and $300 \mathrm{~km}$ could be explained by resuspension of river sediment because of the small organic fraction in TSS and the lack of floodplain inflows in this area.

\subsection{Dam effects on organic matter composition}

In the Kafue River basin, terrestrial POM is efficiently retained in the ITT reservoir upstream of the Kafue Flats, as indicated by the high sedimentation rates (Kunz et al., 2011) and the elevated $\delta^{13} \mathrm{C}$ and $\mathrm{C}: \mathrm{N}$ in sediments relative to epilimnetic POM (Table S1, Fig. S4, Supplement). This effective particle retention is reflected in the high abundance of DOC ( $>80 \%$ ) relative to total OC, compared to tropical $(61 \%)$ or subtropical $(70 \%)$ catchments (Alvarez-Cobelas et al., 2012).

The observed injection of authigenic, ${ }^{13} \mathrm{C}$-depleted POM from the reservoir's primary production to the river has also been documented in the Beijiang River in China (Chen and Jia, 2009) and in the Tana River in Kenya (Bouillon et al., 2009). In the study of Bouillon et al. (2009), ${ }^{13} \mathrm{C}$-depleted $\mathrm{POM}$ with a $\mathrm{C}$ content of $33 \%$ was measured in the river after a large reservoir. The microbial POC was rapidly mineralized after the dam, which resulted in a rebound in $\delta^{13} \mathrm{C}-\mathrm{POC}$ from 
$-29 \%$ to $-22 \%$. Our flooding season data from the first $90 \mathrm{~km}$ showed a less distinct rebound to values of $-28 \%$, accompanied by a concentration increase (Fig. 3b), which suggests inputs of POM from the floodplain rather than significant in-stream mineralization of POM.

Contrary to the particulate fraction, the primary production in the reservoir had limited influence on the riverine $\delta^{13} \mathrm{C}$-DOC, which is consistent with the study from Bouillon et al. (2009), where river and reservoir $\delta^{13} \mathrm{C}$-DOC were indifferent. This supports the notion that the DOM from the upstream catchment was refractory and not mineralized in significant quantities before entering the Kafue Flats. The lack of a strong microbial DOM signal downstream of ITT dam further suggests that DOM produced in the reservoir was mineralized in situ.

Finally, we observed a $4 \%$ occline in $\delta^{13} \mathrm{C}$-POC (Fig. 4) and a concurrent enrichment in $\mathrm{C}$ and $\mathrm{N}$ of TSS (Fig. 3c) after $\sim 320 \mathrm{~km}$ in the dry season. This lowest section of the Kafue Flats is permanently inundated due to the backwaters of the downstream Kafue Gorge reservoir. As the Kafue was flowing through this area, $\delta^{13} \mathrm{C}-\mathrm{POC}$ declined to values typical for the flooding period, $(-29 \%)$ which may be the result of hydrological exchange with the permanent wetlands and the supply of POM from phytoplankton-dominated sources.

\subsection{Processes affecting the nitrogen budget in the Kafue Flats}

The nitrogen cycle in tropical floodplains is poorly constrained compared to temperate systems (e.g. Hoffmann et al., 2011; Olde Venterink et al., 2003). Our data indicate a large annual $\mathrm{N}$ export from the Kafue Flats mostly in the form of refractory DON. We hypothesized that high Nfixation rates are required to compensate the $\mathrm{N}$ losses. Combining $\mathrm{N}$ fluxes and $\delta^{15} \mathrm{~N}$ signatures, completed by flux estimates from the literature, we obtained a putative $\mathrm{N}$ budget over the flooded area and constrained the $\mathrm{N}$-fixation rates required to balance the $\mathrm{N}$ deficit. The $\mathrm{N}$ fluxes were calculated using our own data and literature values for the Kafue Flats. Denitrification was approximated using conservative rates from a wide range of rivers and floodplains (of $1-4 \mathrm{~g} \mathrm{~N} \mathrm{~m}^{-2} \mathrm{yr}^{-1}$, Table S3, Supplement). For the upstream reservoir, the fluxes have been described by Kunz et al. (2011), who proposed $\mathrm{N}$-fixation rates of $12 \mathrm{~g} \mathrm{~N} \mathrm{~m}^{-2} \mathrm{yr}^{-1}$ to account for the $\mathrm{N}$ losses through export, sediment accumulation and denitrification in the reservoir (Fig. 10a).

For the Kafue Flats, budget calculations revealed an $\mathrm{N}$ deficit of $15500-22100 \mathrm{t} \mathrm{N} \mathrm{yr}^{-1}$, which was 5-7 times higher than the $\mathrm{N}$ input from the reservoir and equal to areal rates of $58-82 \mu \mathrm{mol} \mathrm{N} \mathrm{m}^{-2} \mathrm{~h}^{-1}$ or $7-10 \mathrm{~g} \mathrm{~N} \mathrm{~m}^{-2} \mathrm{yr}^{-1}$, respectively (Fig. 10b). Previous studies in tropical floodplains found $\mathrm{N}$-fixation rates of several $\mathrm{g} \mathrm{N} \mathrm{m}^{-2} \mathrm{yr}^{-1}$ (Cleveland et al., 1999), through symbiotic or asymbiotic fixation by free-floating or attached cyanobacteria (Kern and Darwich, 2003). The ${ }^{15} \mathrm{~N}$ isotope mass balance of the Kafue

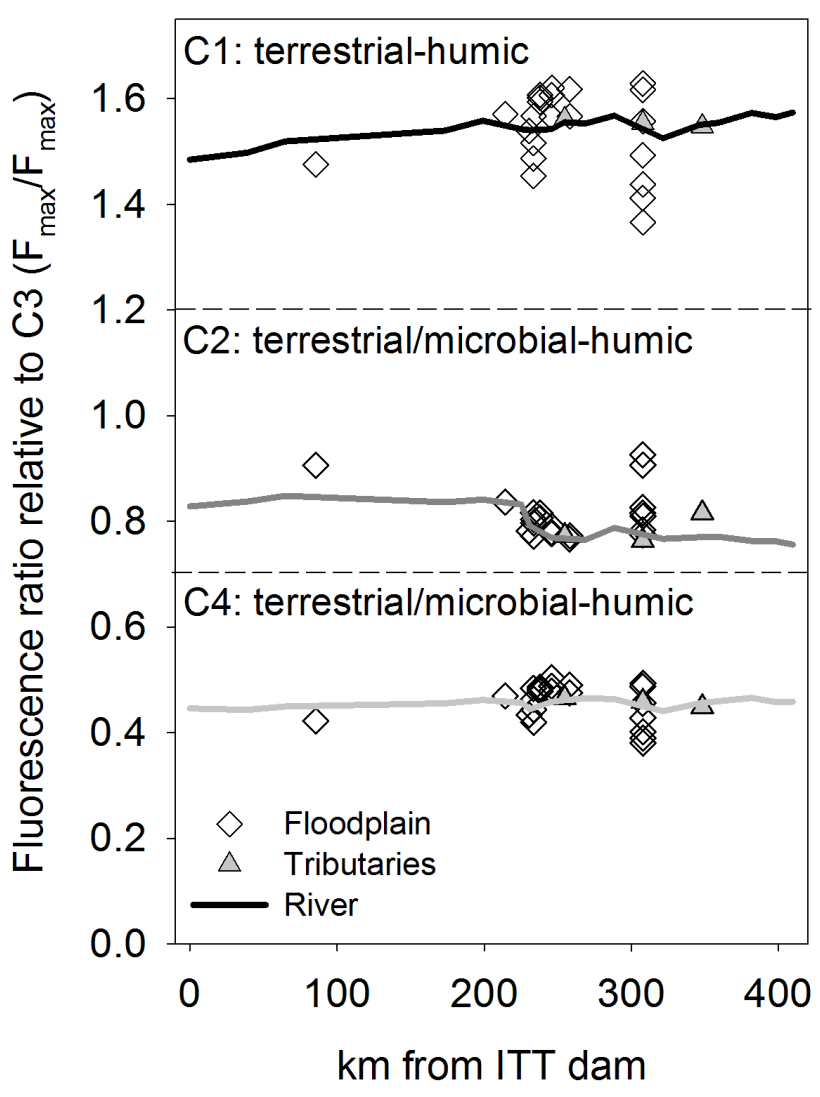

Fig. 9. Ratios of components identified by PARAFAC analysis. Components $\mathrm{C} 1, \mathrm{C} 2$, and $\mathrm{C} 4$ are shown relative to $\mathrm{C} 3$ along the river, in floodplain and tributaries, measured in May 2010.

Flats supports the hypothesis of $\mathrm{N}$-fixation being the main $\mathrm{N}$ source (Fig. 10b). The isotope balance requires a $\delta^{15} \mathrm{~N}$ of $0.8-1.2 \%$ or the calculated $\mathrm{N}$ deficit, which are values close to the $0 \%$ oxpected from the fixation of atmospheric $\mathrm{N}$ (Martinelli et al., 1992).

The $\mathrm{N}$ stable isotope data from the dissolved and particulate fraction provide additional evidence for $\mathrm{N}$-fixation in the Kafue Flats. For the flooding campaigns, $\delta^{15} \mathrm{~N}-\mathrm{PN}$ after the dam reflected the epilimnetic signature of $\sim 4 \%$ o. During the floodplain transit, $\delta^{15} \mathrm{~N}-\mathrm{PN}$ gradually approximated the fairly constant $\delta^{15} \mathrm{~N}$-TDN signal of $\sim 2 \%$ o (Fig. 4). This shift towards $0 \%$ o could imply the increasing contribution of nonsymbiotic $\mathrm{N}$-fixers along the river (Gu and Alexander, 1993; Rejmankova et al., 2004), even though the floodplain $\delta^{15} \mathrm{~N}-$ PN showed considerable heterogeneity (Fig. 4). The $\delta^{15} \mathrm{~N}-$ $\mathrm{PN}$ of $\sim 2 \%$ also persisted during the dry season.

The narrow range of $\delta^{15} \mathrm{~N}-\mathrm{TDN}$ (Fig. 4) did not allow to further discriminate between floodplain DOM and reservoir $\operatorname{DOM}(1.9 \pm 0.4 \%$; Table S1, Supplement), but is consistent with the $\delta^{13} \mathrm{C}$-DOC and DOM spectroscopic data, and supports the paradigm that riverine DON in general originates from terrestrial sources (Berman and Bronk, 2003). Intense cycling of DON would affect the $\delta^{15} \mathrm{~N}-\mathrm{TDN}$, as shown by 


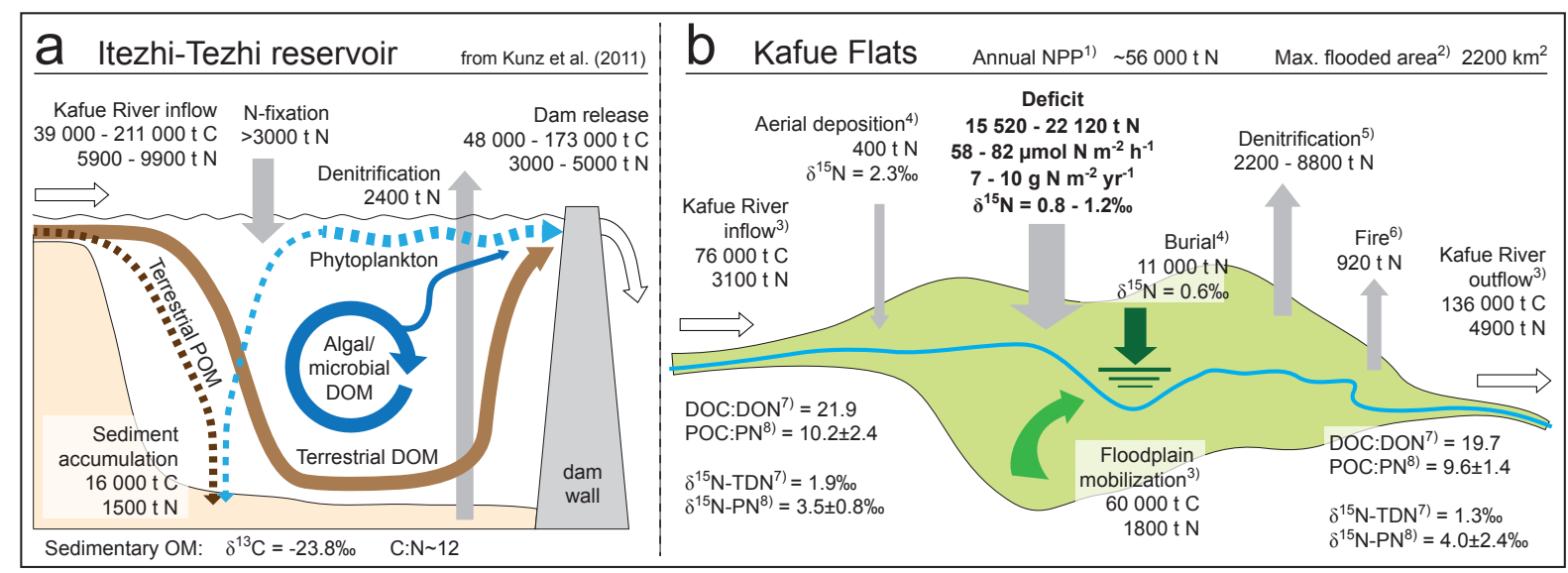

Fig. 10. (a) Schematic illustration of the annual $C$ and $N$ fluxes in ITT reservoir from Kunz et al. (2011). (b) System-scale N balance of the Kafue Flats based on our own data from 2008-2010 and literature values: (1) Estimated based on Ellenbroek (1987); (2) data from the inundation model of Meier et al. (2010); (3) data from Wamulume et al. (2011); (4) deposition based on trap data, burial from sediment cores (Zurbrügg, unpublished); (5) estimated from literature data (Table S3, Supplement); (6) burnt areas from Munyati (2000); (7) data from October 2008, May 2009, and May 2010; (8) mean \pm SD from annual sampling campaign (Fig. S3, Supplement).

Schlarbaum et al. (2011) who found variation of more than $10 \%$ o due to release and uptake of DON in a temperate estuary. Compensating $\mathrm{N}$ isotopic fractionation that would result in no net change in $\delta^{15} \mathrm{~N}-\mathrm{TDN}$, e.g. from concomitant release, uptake, and degradation along the main channel cannot be completely excluded, but is considered unlikely (Knapp et al., 2005).

The high abundance of periphyton on inundated vegetation and the high diversity and spreading of $\mathrm{N}$-fixing plants in the floodplain (Ellenbroek, 1987) indicate that $\mathrm{N}$-fixation also occurred through attached and symbiotic fixers. $\mathrm{N}$ that was fixed through trees and shrubs outside the flooded area, and deposited through seasonal tributaries could be an additional $\mathrm{N}$ source to the floodplain. Complementary measurements of $\mathrm{N}$ pools across the Kafue Flats fell in a relatively narrow range ( -1 to $4 \%$; Table S1, Supplement). This range is within the data range reported for the Amazon floodplains (Aufdenkampe et al., 2007; Hedges et al., 2000; Bernardes et al., 2004) and might be characteristic for such systems.

\section{Conclusions}

Intense river-floodplain exchange during the flooding period caused a net export of $69-111 \mathrm{~kg} \mathrm{C} \mathrm{km}^{-2} \mathrm{~d}^{-1}$ in the form of DOC from the Kafue Flats, which exceeded specific export rates predicted for the Amazon or the Congo River basins by a factor of 5 or more $\left(5-14 \mathrm{~kg} \mathrm{C} \mathrm{km}^{-2} \mathrm{~d}^{-1}\right.$; Harrison et al., 2005; Mayorga et al., 2010). During the dry season, the Kafue Flats were a net sink of OM, but during the wet season and over an annual cycle, $\mathrm{C}$ and $\mathrm{N}$ export exceeded import. Significant $\mathrm{N}$ losses through export, burial and denitrification caused an annual $\mathrm{N}$ deficit of $15500-22100 \mathrm{tN}$ which must be balanced by high $\mathrm{N}$-fixation rates of $7-10 \mathrm{~g} \mathrm{~N} \mathrm{~m}^{-2} \mathrm{yr}^{-1}$ (Fig. 10b).

Stable isotope and spectroscopic analyses showed that DOM in the Kafue River was dominated by terrestrial sources along the entire reach, despite several months residence time in the upstream reservoir. River DOM characteristics did not vary substantially as floodplain waters increased the DOC and DON loads by a factor of 3, which indicates that DOM leaving the reservoir was likely from refractory terrestrial sources. The exported POM was clearly distinguishable from DOM by its overall lower $\mathrm{C}: \mathrm{N}$ ratio and more negative $\delta^{13} \mathrm{C}$. Both indicators suggest planktonic or microbial sources for POM from the reservoir and floodplain primary production. Marked differences between the flooding and the dry season showed that the in-stream processes were small compared to the organic matter pulses from the floodplain.

Our study underlines how intense river-floodplain exchange fosters high DOM exports to a tropical river basin. In contrast to forested systems like the Amazon, in the flooded grassland ecosystem of the Kafue Flats, the aquatic primary production from the floodplain was a more important POM source than plant debris or soil/sedimentary OM. Finally, the upstream reservoir had a strong effect on the quality of POM by replacing terrestrial particles with OM from autochthonous sources, while its impact on the DOM pool was small.

\author{
Supplementary material related to this article is

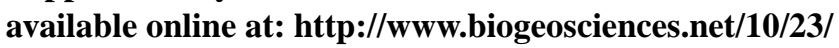 \\ 2013/bg-10-23-2013-supplement.pdf.
}


Acknowledgements. The authors thank Jason Wamulume, Griffin Shanungu, Manuel Kunz, Wilma Blaser, and Event Ngandu, and the ZAWA wildlife officers for assistance during field work; Mark Rollog (University of Basel), Ruth Stierli (Eawag), Kate Ashe, the ETHZ Soil Chemistry and Environmental Chemistry groups for laboratory support, Britt Peterson (ETHZ) for assistance with excitation-emission spectroscopy analyses, Linda Jørgensen (University of Copenhagen) and Dolly Kothawala (University of Uppsala) for support with PARAFAC modeling and interpretation. This study was supported by the following Zambian partners and agencies: Imasiku Nyambe (University of Zambia), Zambia Wildlife Authority, Zambia Electricity Supply Corporation (ZESCO), Zambezi River Authority, and Department of Water Affairs. We also acknowledge the helpful comments of the two anonymous reviewers and the handling editor, Steven Bouillon, which significantly improved the manuscript. Funding was provided by the Competence Center for Environment and Sustainability (CCES) of the ETH domain, the Swiss National Science Foundation (Grant No. 128707), and Eawag.

Edited by: S. Bouillon

\section{References}

Aalto, R., Maurice-Bourgoin, L., Dunne, T., Montgomery, D. R., Nittrouer, C. A., and Guyot, J. L.: Episodic sediment accumulation on Amazonian flood plains influenced by El Niño/Southern Oscillation, Nature, 425, 493-497, doi:10.1038/nature02002, 2003.

Alin, S. R., Aalto, R., Goni, M. A., Richey, J. E., and Dietrich, W. E.: Biogeochemical characterization of carbon sources in the strickland and fly rivers, Papua New Guinea, J. Geophys. Res.Earth Surface, 113, F01s05, doi:10.1029/2006jf000625, 2008.

Alvarez-Cobelas, M., Angeler, D. G., Sanchez-Carrillo, S., and Almendros, G.: A worldwide view of organic carbon export from catchments, Biogeochemistry, 107, 275-293, doi:10.1007/s10533-010-9553-z, 2012.

Aufdenkampe, A. K., Mayorga, E., Hedges, J. I., Llerena, C., Quay, P. D., Gudeman, J., Krusche, A. V., and Richey, J. E.: Organic matter in the Peruvian headwaters of the Amazon: Compositional evolution from the Andes to the lowland Amazon mainstem, Org. Geochem., 38, 337-364, doi:10.1016/j.orggeochem.2006.06.003, 2007.

Battin, T. J., Luyssaert, S., Kaplan, L. A., Aufdenkampe, A. K., Richter, A., and Tranvik, L. J.: The boundless carbon cycle, Nature Geosci., 2, 598-600, doi:10.1038/ngeo618, 2009.

Berman, T. and Bronk, D. A.: Dissolved organic nitrogen: a dynamic participant in aquatic ecosystems, Aquat. Microb. Ecol., 31, 279-305, 2003.

Bernardes, M. C., Martinelli, L. A., Krusche, A. V., Gudeman, J., Moreira, M., Victoria, R. L., Ometto, J., Ballester, M. V. R., Aufdenkampe, A. K., Richey, J. E., and Hedges, J. I.: Riverine organic matter composition as a function of land use changes, Southwest Amazon, Ecol. Appl., 14, S263-S279, 2004.

Bouillon, S., Dehairs, F., Schiettecatte, L. S., and Borges, A. V.: Biogeochemistry of the Tana estuary and delta (northern Kenya), Limnol. Oceanogr., 52, 46-59, 2007.

Bouillon, S., Abril, G., Borges, A. V., Dehairs, F., Govers, G., Hughes, H. J.,Merckx, R., Meysman, F. J. R., Nyunja, J., Os- burn, C., and Middelburg, J. J.: Distribution, origin and cycling of carbon in the Tana River (Kenya): a dry season basin-scale survey from headwaters to the delta, Biogeosciences, 6, 2475-2493, doi:10.5194/bg-6-2475-2009, 2009.

Bourbonnais, A., Lehmann, M. F., Waniek, J. J., and Schulz-Bull, D. E.: Nitrate isotope anomalies reflect $\mathrm{N}_{2}$ fixation in the Azores Front region (subtropical NE Atlantic), J. Geophys. Res.-Oceans, 114, doi:10.1029/2007jc004617, 2009.

Braman, R. S. and Hendrix, S. A.: Nanogram nitrite and nitrate determination in environmental and biological materials by vanadium(III) reduction with chemiluminescence detection, Anal. Chem., 61, 2715-2718, 1989.

Bronk, D. A., Lomas, M. W., Glibert, P. M., Schukert, K. J., and Sanderson, M. P.: Total dissolved nitrogen analysis: comparisons between the persulfate, UV and high temperature oxidation methods, Mar. Chem., 69, 163-178, 2000.

Casciotti, K. L., Sigman, D. M., Hastings, M. G., Böhlke, J. K., and Hilkert, A.: Measurement of the oxygen isotopic composition of nitrate in seawater and freshwater using the denitrifier method, Anal. Chem., 74, 4905-4912, 2002.

Chen, F. J. and Jia, G. D.: Spatial and seasonal variations in $\delta^{13} \mathrm{C}$ and $\delta^{15} \mathrm{~N}$ of particulate organic matter in a damcontrolled subtropical river, River Res. Appl., 25, 1169-1176, doi:10.1002/rra.1225, 2009.

Chen, H. and Zheng, B. H.: Characterizing natural dissolved organic matter in a freshly submerged catchment (Three Gorges Dam, China) using UV absorption, fluorescence spectroscopy and PARAFAC, Water Sci. Technol., 65, 962-969, doi:10.2166/wst.2012.939, 2012.

Chen, W., Westerhoff, P., Leenheer, J. A., and Booksh, K.: Fluorescence excitation-emission matrix regional integration to quantify spectra for dissolved organic matter, Environ. Sci. Technol., 37, 5701-5710, doi:10.1021/es034354c, 2003.

Cleveland, C. C., Townsend, A. R., Schimel, D. S., Fisher, H., Howarth, R. W., Hedin, L. O., Perakis, S. S., Latty, E. F., Von Fischer, J. C., Elseroad, A., and Wasson, M. F.: Global patterns of terrestrial biological nitrogen $\left(\mathrm{N}_{2}\right)$ fixation in natural ecosystems, Global Biogeochem. Cy., 13, 623-645, doi:10.1029/1999gb900014, 1999.

Coble, P. G.: Characterization of marine and terrestrial DOM in seawater using excitation emission matrix spectroscopy, Mar. Chem., 51, 325-346, 1996.

Cory, R. M., Miller, M. P., McKnight, D. M., Guerard, J. J., and Miller, P. L.: Effect of instrument-specific response on the analysis of fulvic acid fluorescence spectra, Limnol. Oceanogr.-Meth., 8, 67-78, 2010.

Cotner, J. B., Montoya, J. V., Roelke, D. L., and Winemiller, K. O.: Seasonally variable riverine production in the Venezuelan llanos, J. North Am. Benthol. Soc., 25, 171-184, doi:10.1899/08873593(2006)25[171:SVRPIT]2.0.CO;2, 2006.

Ellenbroek, G. A.: Ecology and productivity of an African wetland system. Geobotany 9, Dr. W. Junk, Dordrecht, 267 pp., 1987.

Ellis, E. E., Richey, J. E., Aufdenkampe, A. K., Krusche, A. V., Quay, P. D., Salimon, C., and da Cunha, H. B.: Factors controlling water-column respiration in rivers of the central and southwestern Amazon Basin, Limnol. Oceanogr., 57, 527-540, doi:10.4319/lo.2012.57.2.0527, 2012.

Galy, V. and Eglinton, T.: Protracted storage of biospheric carbon in the Ganges-Brahmaputra basin, Nature Geosci., 4, 843-847, 
doi:10.1038/ngeo1293, 2011.

Grasshoff, K., Kremling, K., and Ehrhardt, M.: Methods of Seawater Analysis, Third ed., Wiley-VCH, Weinheim, New York, Chichester Brisbane, Singapore, Tokyo, 632 pp., 1999.

$\mathrm{Gu}, \mathrm{B}$. and Alexander, V.: Estimation of $\mathrm{N}_{2}$ fixation based on differences in the natural-abundance of ${ }^{15} \mathrm{~N}$ among fresh-water $\mathrm{N}_{2}$ fixing and non- $\mathrm{N}_{2}$-fixing algae, Oecologia, 96, 43-48, 1993.

Hamilton, S. K. and Lewis, W. M.: Stable carbon and nitrogen isotopes in algae and detritus from the Orinoco River floodplain, Venezuela, Geochim. Cosmochim. Ac., 56, 4237-4246, 1992.

Harrison, J. A., Caraco, N., and Seitzinger, S. P.: Global patterns and sources of dissolved organic matter export to the coastal zone: Results from a spatially explicit, global model, Global Biogeochem. Cy., 19, Gb4s04 doi:10.1029/2005gb002480, 2005.

Hedges, J. I., Mayorga, E., Tsamakis, E., McClain, M. E., Aufdenkampe, A., Quay, P., Richey, J. E., Benner, R., Opsahl, S., Black, B., Pimentel, T., Quintanilla, J., and Maurice, L.: Organic matter in Bolivian tributaries of the Amazon River: A comparison to the lower mainstream, Limnol. Oceanogr., 45, 1449-1466, 2000.

Hoffmann, C. C., Kronvang, B., and Audet, J.: Evaluation of nutrient retention in four restored Danish riparian wetlands, Hydrobiologia, 674, 5-24, doi:10.1007/s10750-011-0734-0, 2011.

Hunsinger, G. B., Mitra, S., Findlay, S. E. G., and Fischer, D. T.: Wetland-driven shifts in suspended particulate organic matter composition of the Hudson River estuary, New York, Limnol. Oceanogr., 55, 1653-1667, 2010.

Ishii, S. K. L. and Boyer, T. H.: Behavior of reoccurring PARAFAC components in fluorescent dissolved organic matter in natural and engineered systems: A critical review, Environ. Sci. Technol., 46, 2006-2017, doi:10.1021/es2043504, 2012.

Johnson, M. S., Lehmann, J., Selva, E. C., Abdo, M., Riha, S., and Couto, E. G.: Organic carbon fluxes within and streamwater exports from headwater catchments in the southern Amazon, Hydrol. Process., 20, 2599-2614, doi:10.1002/hyp.6218, 2006.

Johnson, M. S., Couto, E. G., Abdo, M., and Lehmann, J.: Fluorescence index as an indicator of dissolved organic carbon quality in hydrologic flowpaths of forested tropical watersheds, Biogeochemistry, 105, 149-157, doi:10.1007/s10533-011-9595-x, 2011.

Kern, J. and Darwich, A.: The role of periphytic $\mathrm{N}_{2}$ fixation for stands of macrophytes in the whitewater floodplain (varzea), Amazoniana-Limnologia Et Oecologia Regionalis Systemae Fluminis Amazonas, 17, 361-375, 2003.

Knapp, A. N., Sigman, D. M., and Lipschultz, F.: N isotopic composition of dissolved organic nitrogen and nitrate at the Bermuda Atlantic time-series study site, Global Biogeochem. Cy., 19, GB1018, doi:10.1029/2004gb002320, 2005.

Kunz, M. J., Wüest, A., Wehrli, B., Landert, J., and Senn, D. B.: Impact of a large tropical reservoir on riverine transport of sediment, carbon, and nutrients to downstream wetlands, Water Resour. Res., 47, W12531, doi:10.1029/2011WR010996, 2011.

Lakowicz, J. R.: Principles of Fluorescence Spectroscopy, 3rd Edn., Springer, New York, 954 pp., 2006.

Martinelli, L. A., Victoria, R. L., Trivelin, P. C. O., Devol, A. H., and Richey, J. E.: N-15 natural abundance in plants of the Amazon River floodplain and potential atmospheric $\mathrm{N}_{2}$ fixation, Oecologia, 90, 591-596, 1992.
Mayorga, E., Aufdenkampe, A. K., Masiello, C. A., Krusche, A. V., Hedges, J. I., Quay, P. D., Richey, J. E., and Brown, T. A.: Young organic matter as a source of carbon dioxide outgassing from Amazonian rivers, Nature, 436, 538-541, doi:10.1038/nature03880, 2005.

Mayorga, E., Seitzinger, S. P., Harrison, J. A., Dumont, E., Beusen, A. H. W., Bouwman, A. F., Fekete, B. M., Kroeze, C., and Van Drecht, G.: Global Nutrient Export from WaterSheds 2 (NEWS 2): Model development and implementation, Environ. Modell. Software, 25, 837-853, doi:10.1016/j.envsoft.2010.01.007, 2010.

McJannet, D., Wallace, J., Keen, R., Hawdon, A., and Kemei, J.: The filtering capacity of a tropical riverine wetland: II. Sediment and nutrient balances, Hydrol. Process., 26, 53-72, doi:10.1002/hyp.8111, 2012.

McKnight, D. M., Boyer, E. W., Westerhoff, P. K., Doran, P. T., Kulbe, T., and Andersen, D. T.: Spectrofluorometric characterization of dissolved organic matter for indication of precursor organic material and aromaticity, Limnol. Oceanogr., 46, 38-48, 2001.

Meier, P., Wang, H., Milzow, C., and Kinzelbach, W.: Remote sensing for hydrological modeling of seasonal wetlands - Concepts and applications, ESA Living Planet Symposium, 28 June-2 July 2010, Bergen, Norway, 2010,

Miller, M. P. and McKnight, D. M.: Comparison of seasonal changes in fluorescent dissolved organic matter among aquatic lake and stream sites in the Green Lakes Valley, J. Geophys. Res.Biogeosci., 115, doi:10.1029/2009jg000985, 2010.

Mitsch, W. J. and Gosselink, J. G.: Wetlands, 4th Edn., John Wiley \& Sons Inc., New Jersey, USA, 582 pp., 2007.

Mladenov, N., McKnight, D. M., Wolski, P., and Ramberg, L.: Effects of annual flooding on dissolved organic carbon dynamics within a pristine wetland, the Okavango Delta, Botswana, Wetlands, 25, 622-638, 2005.

Mumba, M., and Thompson, J. R.: Hydrological and ecological impacts of dams on the Kafue Flats floodplain system, southern Zambia, Phys. Chem. Earth, 30, 442-447, 2005.

Munyati, C.: Wetland change detection on the Kafue Flats, Zambia, by classification of a multitemporal remote sensing image dataset, Int. J. Remote Sens., 21, 1787-1806, 2000.

Noe, G. B. and Hupp, C. R.: Retention of riverine sediment and nutrient loads by coastal plain floodplains, Ecosystems, 12, 728746, doi:10.1007/s10021-009-9253-5, 2009.

Olde Venterink, H., Wiegman, F., Van der Lee, G. E. M., and Vermaat, J. E.: Role of active floodplains for nutrient retention in the river Rhine, J. Environ. Qual., 32, 1430-1435, 2003.

Petrone, K. C., Fellman, J. B., Hood, E., Donn, M. J., and Grierson, P. F.: The origin and function of dissolved organic matter in agro-urban coastal streams, J. Geophys. Res.-Biogeosci., 116, 13, G01028, doi:10.1029/2010jg001537, 2011.

Raymond, P. A. and Bauer, J. E.: Riverine export of aged terrestrial organic matter to the North Atlantic Ocean, Nature, 409, 497500, 2001.

Rejmankova, E., Komarkova, J., and Rejmanek, M.: $\delta^{15} \mathrm{~N}$ as an indicator of $\mathrm{N}_{2}$-fixation by cyanobacterial mats in tropical marshes, Biogeochemistry, 67, 353-368, 2004.

Richey, J. E., Mertes, L. A. K., Dunne, T., Victoria, R. L., Forsberg, B. R., S., T. A. C. N., and E., O.: Sources and routing of the Amazon River flood wave, Global Biogeochem. Cy., 3, 191-204, 
1989.

Richey, J. E., Hedges, J. I., Devol, A. H., Quay, P. D., Victoria, R., Martinelli, L., and Forsberg, B. R.: Biogeochemistry of carbon in the Amazon River, Limnol. Oceanogr., 35, 352-371, 1990.

Schlarbaum, T., Dähnke, K., and Emeis, K.: Dissolved and particulate reactive nitrogen in the Elbe River/NW Europe: a 2-yr Nisotope study, Biogeosciences, 8, 3519-3530, doi:10.5194/bg-83519-2011, 2011.

Schwendenmann, L., and Veldkamp, E.: The role of dissolved organic carbon, dissolved organic nitrogen, and dissolved inorganic nitrogen in a tropical wet forest ecosystem, Ecosystems, 8, 339351, doi:10.1007/s10021-003-0088-1, 2005.

Sigman, D. M., Casciotti, K. L., Andreani, M., Barford, C., Galanter, M., and Böhlke, J. K.: A bacterial method for the nitrogen isotopic analysis of nitrate in seawater and freshwater, Anal. Chem., 73, 4145-4153, 2001.

Solórzano, L. and Sharp, J. H.: Determination of total dissolved nitrogen in natural waters, Limnol. Oceanogr., 25, 751-754, 1980.

Spencer, R. G. M., Hernes, P. J., Ruf, R., Baker, A., Dyda, R. Y., Stubbins, A., and Six, J.: Temporal controls on dissolved organic matter and lignin biogeochemistry in a pristine tropical river, Democratic Republic of Congo, J. Geophys. Res.-Biogeosci., 115, G03013, doi:10.1029/2009jg001180, 2010.

Stedmon, C. A., Markager, S., and Bro, R.: Tracing dissolved organic matter in aquatic environments using a new approach to fluorescence spectroscopy, Mar. Chem., 82, 239-254, doi:10.1016/s0304-4203(03)00072-0, 2003.

Stedmon, C. A., and Markager, S.: Resolving the variability in dissolved organic matter fluorescence in a temperate estuary and its catchment using PARAFAC analysis, Limnol. Oceanogr., 50, 686-697, 2005.

Stedmon, C. A. and Bro, R.: Characterizing dissolved organic matter fluorescence with parallel factor analysis: a tutorial, Limnol. Oceanogr.-Meth., 6, 572-579, 2008.

Tamooh, F., Van den Meersche, K., Meysman, F., Marwick, T. R., Borges, A. V., Merckx, R., Dehairs, F., Schmidt, S., Nyunja, J., and Bouillon, S.: Distribution and origin of suspended matter and organic carbon pools in the Tana River Basin, Kenya, Biogeosciences, 9, 2905-2920, doi:10.5194/bg-9-2905-2012, 2012.
Tremblay, L. and Benner, R.: Organic matter diagenesis and bacterial contributions to detrital carbon and nitrogen in the Amazon River system, Limnol. Oceanogr., 54, 681-691, 2009.

Wamulume, J., Landert, J., Zurbrügg, R., Nyambe, I., Wehrli, B., and Senn, D. B.: Exploring the hydrology and biogeochemistry of the dam-impacted Kafue River and Kafue Flats (Zambia), Phys. Chem. Earth, 36, 775-788, doi:10.1016/j.pce.2011.07.049, 2011.

Waterloo, M. J., Oliveira, S. M., Drucker, D. P., Nobre, A. D., Cuartas, L. A., Hodnett, M. G., Langedijk, I., Jans, W. W. P., Tomasella, J., de Araujo, A. C., Pimentel, T. P., and Estrada, J. C. M.: Export of organic carbon in run-off from an Amazonian rainforest blackwater catchment, Hydrol. Process., 20, 2581-2597, doi:10.1002/hyp.6217, 2006.

Weishaar, J. L., Aiken, G. R., Bergamaschi, B. A., Fram, M. S., Fujii, R., and Mopper, K.: Evaluation of specific ultraviolet absorbance as an indicator of the chemical composition and reactivity of dissolved organic carbon, Environ. Sci. Technol., 37, 47024708, doi:10.1021/es030360x, 2003.

Wiegner, T. N., Tubal, R. L., and MacKenzie, R. A.: Bioavailability and export of dissolved organic matter from a tropical river during base- and stormflow conditions, Limnol. Oceanogr., 54, 1233-1242, doi:10.4319/lo.2009.54.4.1233, 2009.

Yamashita, Y., Maie, N., Briceno, H., and Jaffé, R.: Optical characterization of dissolved organic matter in tropical rivers of the Guayana Shield, Venezuela, J. Geophys. Res.-Biogeosci., 115, G00f10, doi:10.1029/2009jg000987, 2010a.

Yamashita, Y., Scinto, L. J., Maie, N., and Jaffé, R.: Dissolved organic matter characteristics across a subtropical wetland's landscape: Application of optical properties in the assessment of environmental dynamics, Ecosystems, 13, 1006-1019, doi:10.1007/s10021-010-9370-1, 2010b.

Ziegler, S. E. and Brisco, S. L.: Relationships between the isotopic composition of dissolved organic carbon and its bioavailability in contrasting Ozark streams, Hydrobiologia, 513, 153-169, doi:10.1023/B:hydr.0000018180.54292.47, 2004.

Zurbrügg, R., Wamulume, J., Kamanga, R., Wehrli, B., and Senn, D. B.: River-floodplain exchange and its effects on the fluvial oxygen regime in a large tropical river system (Kafue Flats, Zambia), J. Geophys. Res.-Biogeosci., 117, doi:10.1029/2011jg001853, 2012. 